\title{
THE SITTING HEIGHT
}

\author{
ROBERT BENNETT BEAN \\ Laboratory of Anatomy, University of Virginia
}

CONTENTS

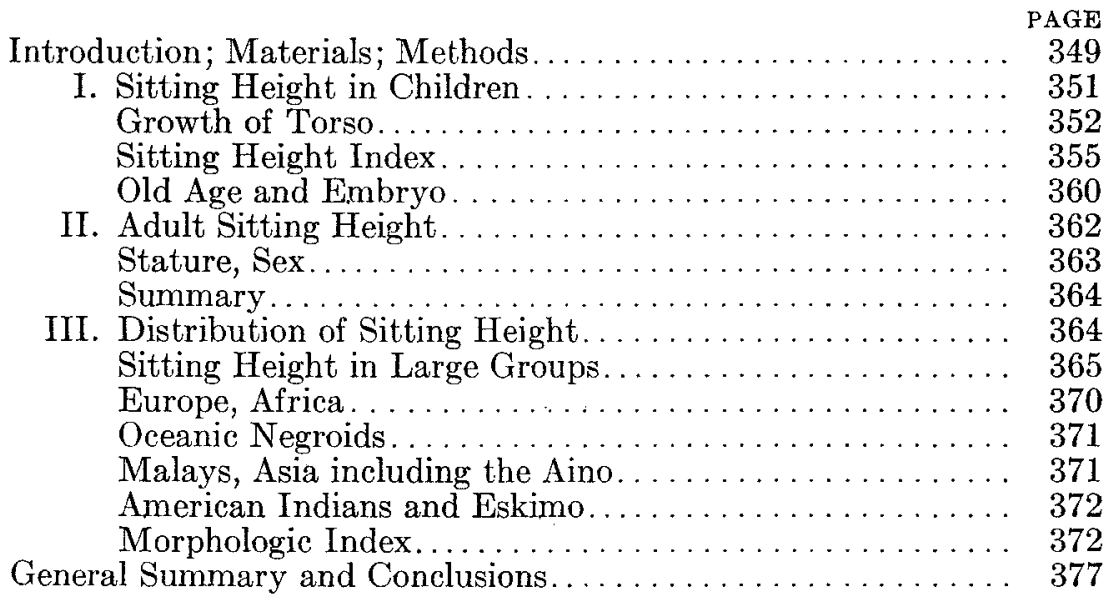

\section{INTRODUCTION}

The sitting height is important in the measurement of the living and it is easy to obtain. It represents the distance between the vertex of the cranium and the line connecting the tuberosities of the ischium, parts covered with a minimum of tissue even in the fat and muscular, and it is therefore exact. It also gives the length of both the torso and the legs.

The trochanter height and the pubic height, which have also been used considerably in anthropometry, are difficult to obtain with accuracy. Thick muscles and fascia and sometimes fat cover the trochanter, so that its upper border cannot be determined exactly, and the error in measuring from the ground especially when it is rough is apt to be great. The measurement of the pubic height is still more difficult to obtain because of the trouble to find the upper border of the pubis, or even the pubic spine, and because of the nature and sensitiveness of this region. The pubis may be high in some people and low in others depending upon the tilting of the pelvis backward or forward, the shape or posture of the vertebral column, the length or strength of the abdominal muscles, or from other causes. The position of the ischial 
tuberosities is not affected by the tilting of the pelvis to the same extent as the pubis because the latter may be raised or lowered whereas the ischium would remain in almost the same horizontal plane. The posture may be controlled better when sitting than when standing, and this gives the advantage to the sitting height. The length and strength of the abdominal muscles admit of greater variation in the vertical position of the pubis than of the ischium. The height of the pubis does not give a good basis for the length of the torso or of the legs. For these and possibly other reasons the sitting height should be taken whenever either the length of the torso, or of the trunk, or of the legs, is desired.

The measurements can best be made with Hrdlička's instruments, methods, and technique. Care is necessary to be sure that the vertebral column is pressed firmly against the upright in the dorsal and sacral regions.

Materials. The materials for the present study include the measurements of the following persons:

1445 white children of Ann Arbor, Mich.

776 Filipino children of Manila.

377 male Filipino students, 18 years or over

183 Filipino men of Taytay

38 Indian-Filipino men of Cainta.

63 Filipino women of Taytay. 688 Negro soldiers of Camp Gordon, Ga.
583 Negro soldiers of Camp Lee, Va.

610 white soldiers of Camp Lee, Va.

523 white soldiers of Camp Gordon Ga.

444 engineers, Motor Truck Camp Univ. of Va.

439 engineers, Motor Truck Camp and students, Univ. of Va.

50 Professors and students, Univ. of Va.

These 6,219 persons were measured by the author except 50 at the University and some at Camp Gordon. The literature has been searched for the past five years and records of nearly 250,000 others were obtained.

Methods. The present report is divided into three parts: I. The sitting height in children; II. The sitting height in the adult; and III. The distribution of the sitting height.

The age given is that of the nearest birthday.

The measurements were taken in a uniform manner, after instruction by Manouvrier and Hrdlička, ${ }^{1}$ the person standing or seated on a plat-

${ }^{1} v$. Hrdlička, A. Anthropometry. Phila. (Wistar Inst.), 1921. 
form against a vertical scale, with a sliding square pressed down properly upon the head. Several direct readings were made of both stature and sitting height. The sitting height will be called the torso.

\section{The Sitting Height in Children}

The materials for this part are from children measured by the author in Ann Arbor, Michigan, in 1906-7 and in Manila, P. I. in 1907-8.

The children of Ann Arbor were partly British American, whose parents were from Canada and the United States, partly German American, one or both parents being of German extraction.

The children of Manila were attending the Trade and Normal schools from all parts of the Philippines, except the young children who were from Manila and vicinity. They represent the more stable and progressive elements in the Philippines, many of whom are Chinese and Spanish Mestizos. They show a preponderance of yellow-brown blood, with traces of Negrito.

A word about the Filipinos may not here be amiss. The Filipino is essentially a Malay, and the Malay is largely a mixture of the southern Asiatic with the Negrito. The southern Asiatic is in turn a mixture of the White (Mediterranean and Indo-European), Yellow-Brown (Mongolian) and Black (Negrito), three fundamental world stocks. The Malay was formed by a continually recurrent fusion of the southern Asiatic with the Negrito who inhabited southern Asia and the adjacent islands. Wave after wave of these people passed out into the Pacific and each was of a slightly different composition. Thus each locality in the Philippines and the islands adjacent thereto is slightly different from the other in the characteristies of the people. There still remain pure Negritos in the Mariveles Mountains and along the east coast of Luzon. Recent Mohammedan (Arabian) movements spread over the Philippines during the 200 years before the Spanish came, and there has been considerable fusion of the Spanish and other European nationalities with the Filipinos during the past 300 years. East Indians have come into the Philippines directly from time to time, and there has been an infiltration of the Chinese for possibly a thousand years: The small trade of the islands is largely in the hands of the Chinese and their Mestizo descendants, who are among the best families in the littoral region of the archipelago.

The majority of the students of the Trade and Normal Schools in the Philippines are from the littoral population of the archipelago, although some come from the inland tribes, some are mixed Negritos 
and a few are pure Europeans. It would have been futile to attempt to segregate the component elements among the students because color and other characteristics obscure conditions; therefore all the records are included. Notes however were made at the time the records were taken as to whether European, Mongolian or Negro characteristics predominated in each individual, and these will be utilized. The following table gives the number of persons at each age measured by the author.

Table I. The Number of Persons at Each Age.

\begin{tabular}{|c|c|c|c|c|c|c|}
\hline \multicolumn{4}{|c|}{ Boys } & \multicolumn{3}{|c|}{ Giris } \\
\hline Age & $\begin{array}{c}\text { British } \\
\text { American }\end{array}$ & $\begin{array}{l}\text { German } \\
\text { American }\end{array}$ & Filipino & $\begin{array}{c}\text { British } \\
\text { American }\end{array}$ & $\begin{array}{c}\text { German } \\
\text { American }\end{array}$ & Filipino \\
\hline 5 & 5 & & & & & \\
\hline 6 & 20 & 22 & & 21 & 16 & \\
\hline 7 & 44 & 30 & 27 & 33 & 28 & 5 \\
\hline 8 & 32 & 33 & & 46 & 28 & \\
\hline 9 & 31 & 36 & & 42 & 31 & \\
\hline 10 & 44 & 44 & & 43 & 36 & \\
\hline 11 & 49 & 45 & 34 & 36 & 43 & 14 \\
\hline 12 & 57 & 33 & & 49 & 43 & \\
\hline 13 & 31 & 33 & 18 & 44 & 33 & 6 \\
\hline 14 & 37 & 31 & 20 & 49 & 11 & 12 \\
\hline 15 & 33 & 12 & 43 & 27 & 13 & 15 \\
\hline 16 & 22 & 3 & 65 & 17 & 8 & 19 \\
\hline 17 & 8 & & 105 & & & 27 \\
\hline 18 & & & 124 & & & \\
\hline 19 & & & 78 & & & 29 \\
\hline 20 & & & 54 & & & \\
\hline $20+$ & & & 63 & & & 18 \\
\hline
\end{tabular}

THE GROWTH OF THE TORSO

The principal results of the study as to the growth of the torso will best be seen in the accompanying chart. Some of the important facts to be noted are that the torso is longer at each age in the British Americans than in the Filipinos, while the German Americans are in between, in both boys and girls; the torso of the girls is longer than that of the boys up to the age of 16 years, except for a short period between 7 and 10 when the torso of the boys is longer; the torso of the Filipino girls is longer than that of the boys up to 11 years, after which there is some irregularity up to the age of 15 when the torso of the boys becomes decidedly longer than that of the girls and so remains; the most rapid growth of the torso is usually from 10 to 12 years in girls and from 11 to 
15 in boys, but in the Filipinos this is from 13 to 15 in girls and from 13 to 17 in boys; this increase in the rate of growth is delayed in German

The actual growth of the torso (Personal measurements).

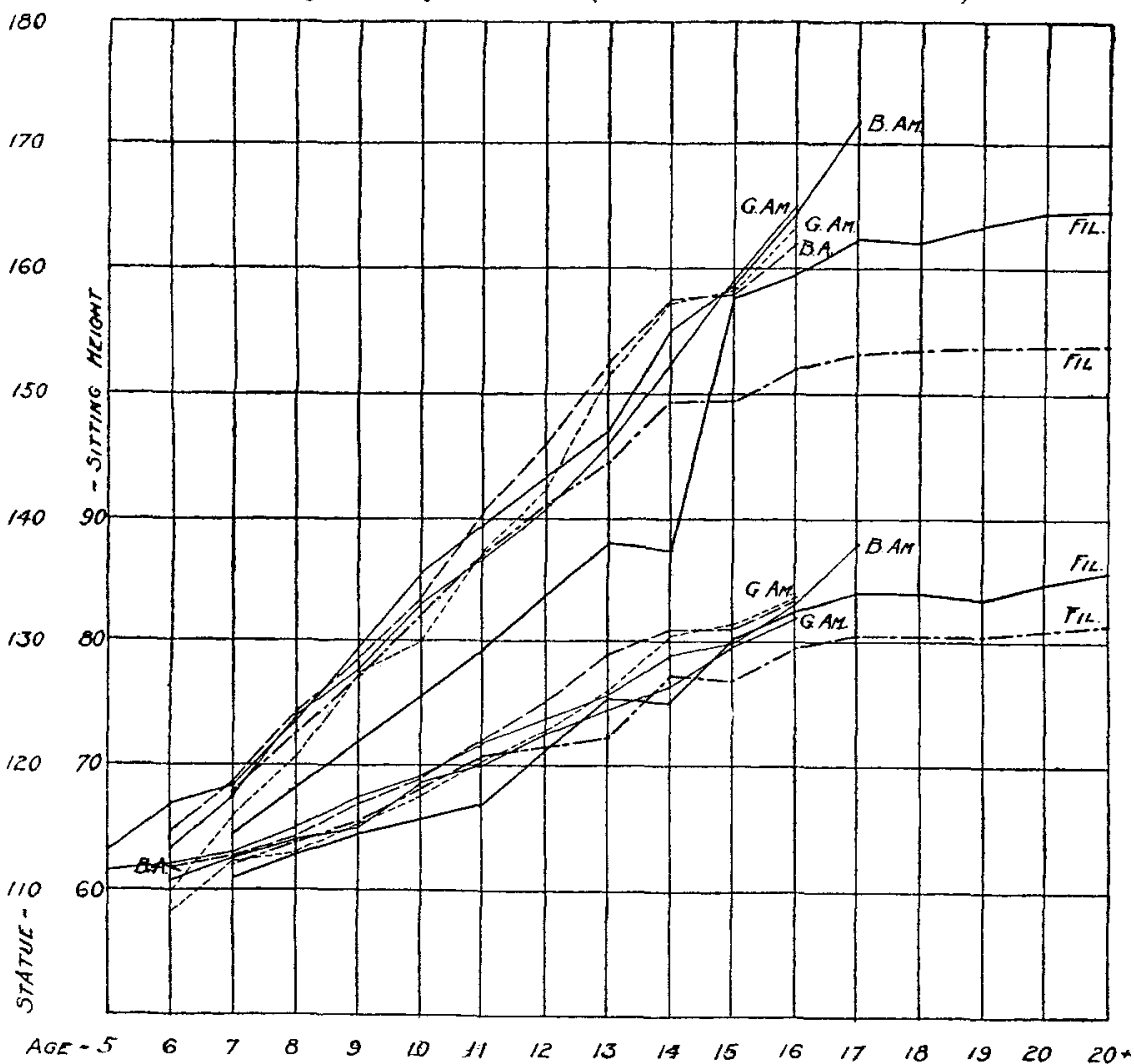

Cinart I. The solid lines represent males, the broken lines females. B. Am. is British American, G. Am. is German American, Fil. is Filipino. From measurements made by the author.

American children as compared to English American; in the Filipinos it is delayed more than in either and occurs two years later than in British American children; and in general the rate of growth in stature increases in girls to about the age of 11 years and in boys to about the age of 16 , after which it decreases.

It may be of some interest to note that at the period of least variability in stature and torso the death rate in children in general is least. What relation there is between the two phenomena, if any, remains to be determined. 
In other racial groups the growth of the torso appears as follows:

The actual growth of the torso. (Other groups).

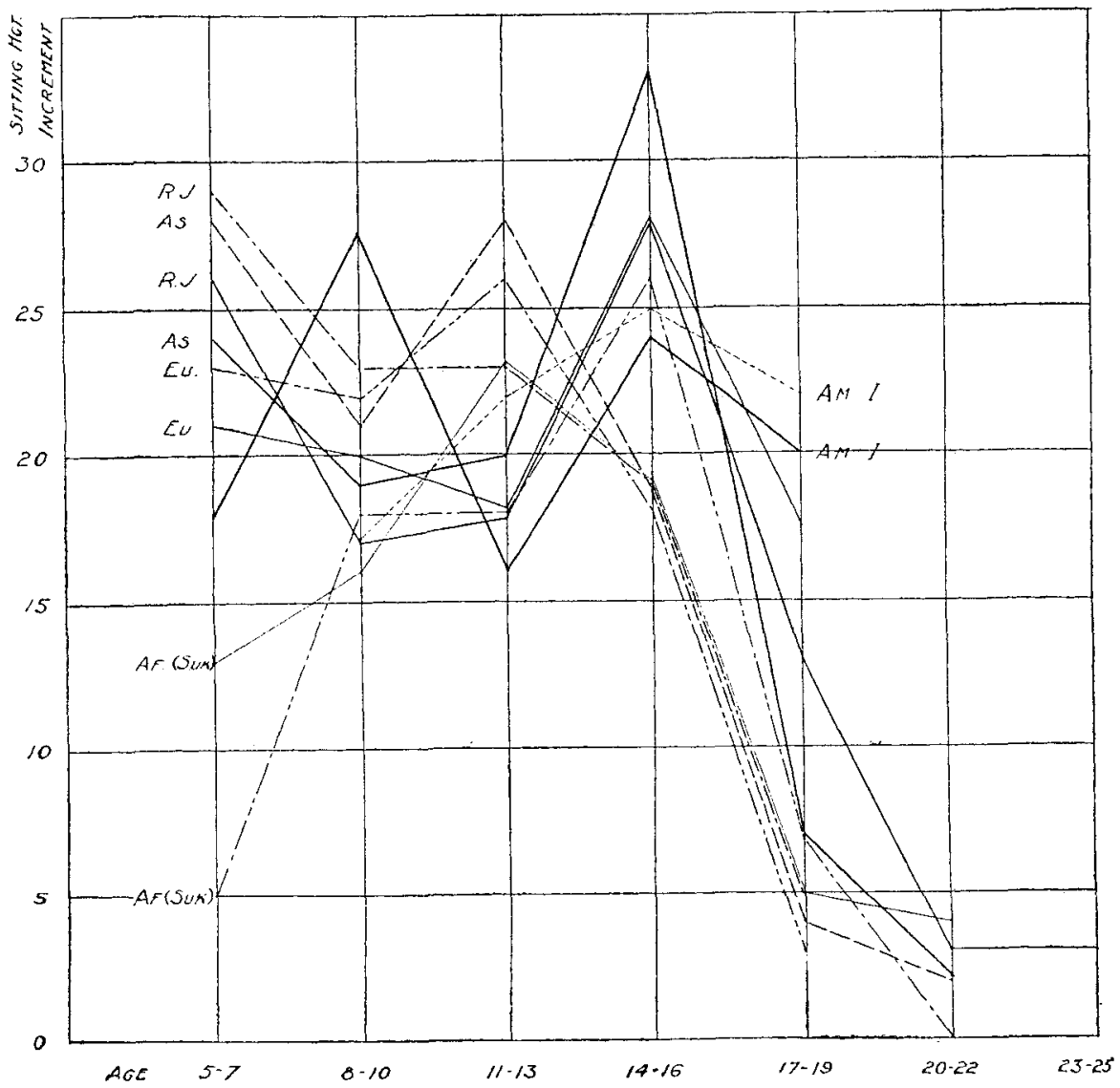

Chart II. The solid lines represent males, the broken lines females. Af. (Suk) are records of the Bantu Zulus of south Africa kindly furnished by Dr. Suk of Bohemia. As. are records of Chinese by Bobbitt and Pyle and Filipinos by Bobbitt and Bean.

Eu. are records of Germans by Ranke, and American whites by Hrdlička, Hastings Smedley and Bean.

Am. I. are records of American Indians at approximate ages by Hrdlička.

R. J. are records of Russian Jews by Weissenberg.

The average yearly increment in growth of the torso from 5 to 22 years, for males, is $1.82 \mathrm{~cm}$. in Asiatics, 1.54 in Europeans, 1.35 in Africans; and for females it is 1.45 for Asiatics, 1.34 for Europeans, and 1.23 for Africans. The growth of the torso is greater in the Chinese and 
Filipinos than in the other groups, and is the least in the Negroes, with the Europeans between. The exception to this. is that the growth in the American Negro girls (mostly of mixed blood, negro-white) is equal to that of the other girls. The Russian Jews appear to be the most precocious in the growth of the torso among the European groups, the Germans seem the most retarded, and the English Americans are in between. The causes of these differences need determination.

According to the data the torso seems to have two periods of rapid growth, the first from 5 to 7 years in boys and girls alike, the second from 11 to 13 years in girls and 14 to 16 in boys. In the Filipinos and Chinese there seems to be a third period after the age of 20 years, but this needs confirmation. The torso of Asiatic boys and girls grows however more in the second period than that of any of the other groups. In American Negroes the most rapid growth period comes later than in other groups, and the growth of the torso is less. The first period of rapid growth in American Negro and also American Indian boys comes from 8 to 10 years instead of from 5 to 7 as usual.

The torso of the girls grows 5 per cent more than that of the boys between the ages of 5 and 16 years, but the torso of the boys grows more after this.

\section{THE SITTING HEIGHT INDEX}

The sitting height index is the sitting height or torso in terms of the stature taken as 100. It serves well as an indicator of growth relationships, because when it reaches its lowest mark it represents the time at which the rapid growth of the lower extremities decreases and the rapid growth of the torso increases.

The lower extremities are seen to grow more rapidly than the torso up to the following ages: British American girls 11 years; German American girls 13 years; Filipino girls 13 years; British American boys 15 years; German American boys 16 years; Filipino boys 14 years.

After the ages given above the torso grows more rapidly than the lower extremities. The age at which this change takes place is earlier in girls than in boys; it is earlier in the Filipinos than in the British Americans, and earlier in the latter than in the German Americans.

We have already seen that the most rapid growth of the torso occurs later in the Filipinos than in the American whites. We now see that the growth of the torso is relatively greater than the lower extremities at an earlier age in the Filipinos than in the American whites. This means that the growth of the lower extremities slows down earlier in the 
Filipinos than in the American whites. We recorded in a previous paper on stature and the teeth (Am.J. Anat., 1914), that the Filipinos are precocious in the periods of acceleration in stature compared to American whites, and we see from chart I that their definitive stature is

The Sitting Height Index (Personal Measurements).

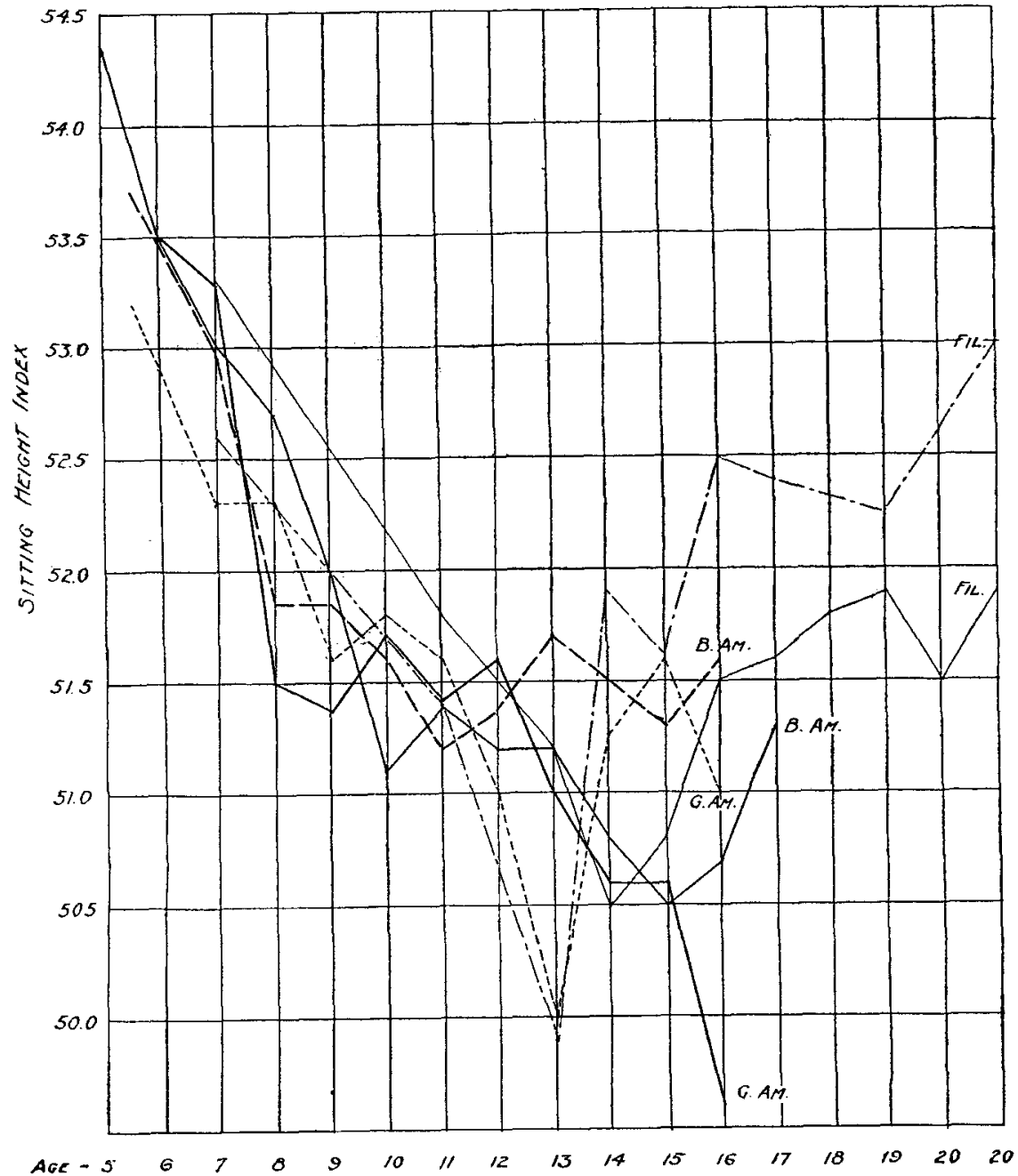

Chart III. The solid lines represent males, the broken lines females. B. Am. are records of British American children, Fil. of Filipino children, and G. Am. of German American children, measured by the author. 
reached at an earlier age than is that of American whites. We also note from charts II and III that the Filipinos and other Asiatics have a more rapid growth of the torso during the periods of its rapid growth than is found in other groups. We may infer from the above that the Asiatics are precocious in the growth of the lower extremities which produces a precocity in stature, because after birth the stature follows the length of the lower extremities more than it does that of the torso as the result of the greater growth of the former than of the latter. There is an apparent precocity of the torso growth as represented by the sitting height index in Asiatics, because of the lag in the growth of the lower extremities at an early period. The early cessation in growth of the lower extremities and the more rapid growth of the torso during the periods of rapid growth produce the condition of long torso and short extremities found so frequently in the Filipinos and other Asiatics. The torso not only grows faster at the periods of most rapid growth but the rapid growth periods extend to a later age in Asiatics than in Europeans.

The Filipino girls have a relatively longer torso before the age of 12 years than the Filipino boys, and their stature is also greater, which is not true of American children, except at the ages of 11 and 12 in the British Americans. After this age the condition is reversed, the Filipino boys have a relatively longer torso than the Filipino girls, whereas the American girls have a longer torso than the boys, although after the age of 14 years the stature of the boys is greater than that of the girls. This indicates a precocity on the part of the Filipino girls that exceeds that of other groups.

Filipino boys have a greater stature and torso length at 13 years than is found in American boys, and the sitting height index reaches its low point and begins to rise earlier in the Filipino than in the British American boys. This is evidence of precocity in the Filipinos. Metamorphosis is earlier as proved by the early cessation of rapid growth in the lower extremities, and the early rapid growth of the torso, as well as the early definitive stature. The Filipino has a later rapid growth of the torso than the American white, and in the Filipino the sitting height index increases more than in the American white after 16 years of age, hence metamorphosis continues later in the Filipino than in the American white. The adult sitting height index of the Filipino is the same as that of the European or American white as we shall see later. This may be the result of the mixture of the Mongolian and Negrito as well as the European in the Filipino: the Negrito with a low sitting height 
index, long duration of the growth of the extremities and short duration of the growth of the torso, the Mongolian with the reverse, and the white in between. The Filipino is nevertheless more like the Mongolian than like the Negrito.

The Sitting Height Index in other Groups.

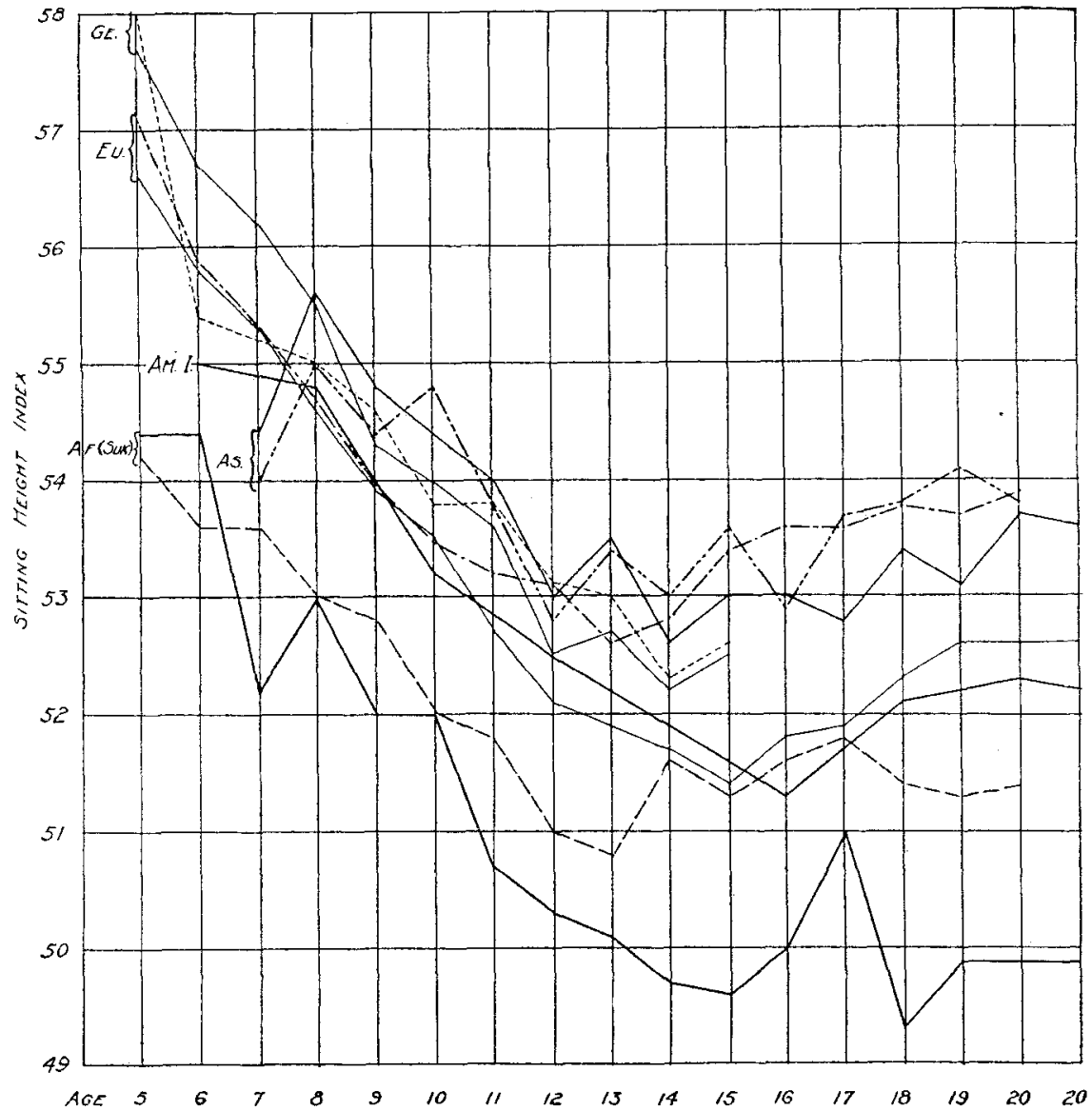

Chart IV. The solid lines are males, the broken lines females.

Af. (Suk) are records of the Bantu-Zulus of south Africa kindly furnished by Dr. Suk of Bohemia.

Am. I are records of American Indians by Hrdlička.

As. are records of Chinese by Bobbitt and Pyle and Filipinos by Bobbitt and Bean.

Eu. are records of American whites by Hrdlička, Hastings, and Smedley.

Ge. are records of Germans by Ranke. 
From Chart IV it may be seen that the time at which the rapidity of growth of the lower extremities begins to decrease and the rapidity of growth of the torso begins to increase varies with different ethnic groups. The list below will illustrate this:

\begin{tabular}{l|l|c|c}
\hline & & Girls & Bors \\
\hline Chinese & (Pyle) & 12 & 14 \\
Chinese & (Bobbitt) & 14 & 14 \\
Filipinos & (Bobbitt) & 12 & 14 \\
Filipinos & (Bean) & 13 & 14 \\
Asylum whites, New York & (Hrdlička) & 13 & 14 \\
School whites & (Smedley, Hastings) & 13 & 15 \\
British Americans & (Bean) & $11 ?$ & 15 \\
Russian Jews & (Weissenberg) & 13 & 15 \\
German Americans & (Bean) & 13 & 16 \\
Germans & (Ranke) & 14 & 14 \\
Asylum Negroes, New York & (Hrdlička) & 14 & 15 \\
School Negroes, Washington, D. C. & (MacDonald) & 13 & 16 \\
Bantus & (Suk) & 11 & 16 \\
Sioux & (Sullivan) & & 13 \\
\hline
\end{tabular}

The girls are more precocious than the boys and the difference is about two years, with the respective ages about 13 and 15 years. In general the Asiatic is in this respect precocious, the African retarded, the European in between.

The average yearly growth of the torso is $2.11 \mathrm{~cm}$. for the female African between 11 and 13 years, 2.57 for the European, and 2.75 for the Asiatic; it is $2.23 \mathrm{~cm}$. for the African male between 14 and 16 years of age, 2.81 for the European, and 3.27 for the Asiatic.

The Negro children in Washington, D. C., have shown an average growth of the torso of more than $2 \mathrm{~cm}$. per year for but six years whereas the white children have the same amount of growth for nine years. The Negro children of Natal and Zululand (Suk's data) have less average yearly growth of the torso than the largely mixed Negro children of Washington.

The torso of the Asiatic begins to grow more rapidly than the lower extremities about a year earlier than in the European, it continues to grow for a longer period of time, grows more after 20 years, grows more rapidly, and is relatively longer in the adult than that of the European except where the Mediterranean or Negrito element predominates, as in India. In a paper written by the author in 1909 ("Filipino Types") the following suggestion was made: "The Filipinos may have an early 
rapid development which is from the European standpoint premature, and a late maturity which is incomplete, at least it looks as if the growth is continued up to a later age in the Filipinos than in the Europeans, but the extent of development is less." The present study seems to confirm that suggestion.

The torso of the American Negro begins to grow more rapidly than the lower extremities at a later date than for the European, and the time of rapid growth is less for the Negro. This is also true of the African Negro. This, in connection with the short torso and long lower extremities in the adult Negro, suggests that the Negro has a long youth and a short adolescence, as suggested by Bardeen.

Bardeen (1920) believes that the Asiatic has a short youth and a long adolescence and the African a long youth and a short adolescence, whereas the European is in between. The result is that the extremities of the Asiatic are predominately relatively short and the torso long, the extremities of the African are long and the torso short, and the European is between. The sitting height index as herein ascertained corroborates this, although the results here may not be conclusive. There is evidence from this study that in general the Chinese and Filipinos conform to the suggested Asiatic type, the American Negro conforms to the suggested African type, and the American white conforms to the suggested European type.

More data are needed at all ages for the Asiatic and the African, and for the late period of growth after the age of 16 years in the European. There are many groups among the peoples of different countries, and variations in growth will no doubt be characteristic of the groups. Even among the Negritos of the Philippines there is more than one anatomical type and this is also true of the Pigmies of Africa. There are nevertheless fundamental tendencies for each of the three continental peoples, the Asiatic, European and African. Derivatives from these three stocks would have the same tendencies. When the three are combined as in the Filipinos all three tendencies may be manifest.

\section{OLD AGE AND EMBRYO}

Stature decreases with advancing age in the adult especially after the age of 60 years, and the torso decreases in length more than the extremities, which results in a lowering of the sitting height index. Whether this is due to "a loss in elasticity in the intervertebral dises," as stated by Bardeen, remains to be seen. There is a shrinkage in all the soft tissues, and this is shared by the discs, but the muscles shrink 
considerably more. The shrinkage of the sacro-spinalis musculature would increase the lumbar curve, and the shrinkage of the dorsal neck muscles would increase the cervical curve of the vertebral column, which would then resemble that of the Negro. The sitting height index in the aged approaches that of the Negro. Pfitzner gives the sitting height index of 303 men from 40 to 60 years of age as 52.7, of 130 men from 60 to 70 years as 51.9, of 100 men from 70 to 80 as 52.0 , and of 27 men from 80 to 90 as 51.6. The condition in the aged is probably the result of several factors, the stoop of age, the shrinkage of the muscles, the shrinkage of the intervertebral dises, and also a slight shrinkage of the long bones. The shrinkage is therefore greater in the torso than in the extremities. Persons beyond the age of 60 years should not be included as normal adults.

Table II. Sitting Height by Stature in the Adult. Pfitzner.

\begin{tabular}{l|c|c|c|c|c}
\hline \multicolumn{1}{c|}{ Stature } & $141-150$ & $151-160$ & $161-170$ & $171-180$ & $181-190$ \\
\hline Male & 53.1 & 52.6 & 52.4 & 52.1 & 51.8 \\
No. & 34 & 277 & 748 & 295 & 9 \\
Female & 53.0 & 52.9 & 52.6 & & \\
No. & 223 & 612 & 197 & 3 & \\
\hline
\end{tabular}

Table III. Sitting Height and Stature by Age in the Adult. Pfitzner.

\begin{tabular}{l|c|c|c|c|c}
\hline \multirow{2}{*}{ Age } & $41-50$ & $51-60$ & $61-70$ & $71-80$ & $81-90$ \\
\hline \multicolumn{6}{c}{ Male } \\
\hline Number & 133 & 173 & 130 & 100 & 27 \\
Stature & 166.2 & 165.3 & 165.4 & 163.6 & 162.2 \\
Index & 52.7 & 52.7 & 51.9 & 52.0 & 51.6 \\
\hline & \multicolumn{7}{|c|}{ Female } & & \\
\hline Number & 92 & 103 & 97 & 105 & 33 \\
Stature & 155.5 & 155.1 & 154.2 & 152.6 & 151.1 \\
Index & 53.1 & 53.0 & 52.5 & 52.1 & 53.1 \\
\hline
\end{tabular}

Streeter in an article entitled "Weight, sitting height, head size, foot length and menstrual age of the human embryo" (Carneg. Inst., Pub. 274,1920 ), shows in table 1 that the sitting height grows more rapidly from the 12th to the 18th week of intrauterine life than before or after, 
and there is a slight retardation in growth between the 28th and 36th week. This wavelike growth is found after birth as already pointed out, the periods of rapid growth being about the seventh and eleventh years, at times when the permanent teeth are erupting most rapidly and the long bones of the extremities are growing more slowly. This illustrates the law of alternation in development as already stated by me in a paper on the teeth. (Am.J. Anat., 1914).

\section{The Adult Sitring Height}

The average sitting height index for each group measured will next be given. The term index will be used to mean the sitting height index, unless otherwise specified.

Table IV. The Average Relative Sitting Height in the Adult.

\begin{tabular}{l|r|l|c|c|c}
\hline \multicolumn{1}{c|}{ Group } & No. & \multicolumn{1}{|c|}{ Race } & Stature & Index & Sit. ht. \\
\cline { 2 - 5 } Manila students & 377 & Mestizo-Malay & 163.3 & 52.5 & 85.6 \\
Taytay men & 183 & Malay & 159.5 & 52.6 & 84.0 \\
Cainta men & 38 & Malay-Indian & 160.9 & 52.2 & 83.8 \\
Taytay women & 63 & Malay & 147.8 & 53.1 & 78.4 \\
Camp Gordon & 688 & Negro-American & 172.9 & 50.5 & 87.3 \\
Camp Lee & 583 & Negro-American & 169.7 & 51.0 & 86.6 \\
Camp Lee & 610 & White & 172.4 & 52.7 & 90.6 \\
Camp Gordon & 523 & White & 174.8 & 52.3 & 91.2 \\
Motor Truck Camp & 444 & White & 174.1 & 52.3 & 91.0 \\
Students, soldiers and & & & & & \\
$\quad$ instructors & 489 & White & 173.8 & 52.0 & 90.4 \\
\hline
\end{tabular}

Race. The Negro records are placed between those of the Filipinos and the American whites to show readily the differences. Pfitzner has demonstrated that the leg length varies directly with stature, therefore the index varies inversely with stature; in the tall the legs are relatively long and the torso relatively short, and in the small the reverse. This is true only within the race (see tables 5 and 6). The American whites and the Filipinos have the same sitting height index although the American whites are 10 centimeters taller than the Filipinos, and the Negroes have a smaller index than the American whites although not so tall.

The small index in the Negro is the result in part at least of the short, sinuous trunk of the Negro. The Negro trunk has marked convexities forward in the lumbar and cervical regions and backward in the thoracic and sacral regions. This was observed by me for several years in the dissecting room, and at Camps Lee and Gordon many Negroes showed this condition on inspection. It is more pronounced in the 
true Negro than in the frequent mixed American Negro. When the sitting height of the Negro was taken the vertebral column would not touch the wall in the cervical and lumbar regions, the back could not be straightened, the thorax and buttocks projected backward and the head and abdomen forward. The head can be brought into line with the thorax and buttocks behind only by elevating the chin. The legs of the Negro are thrown back at the hips, the pelvis is tilted forward to bring the body to the center of gravity, the spinalis musculature is contracted to pull back the trunk and thus maintain the erect posture. The lumbar curve is thereby increased. The abdominal muscles pull the upper ribs and sternum forward and downward because of their tension as a result of the tilting of the pelvis, the protrusion of the lumbar vertebrae into the abdomen, and the action of the spinalis musculature, thereby increasing the dorsal convexity. The result is a shortened torso and relatively long legs. This may also help to explain the backward protrusion of the buttocks and thorax, and the forward protrusion of the head and abdomen in the Negro, which gives them the appearance of having a rugged muscular torso. The short trunk may be caused partly by mechanical factors, though malnutrition may play a part, but the posture, relaxation, burden bearing, flat foot, and muscular pull also contribute, although the primary cause of the increased curvatures of the Negro spine is the effort to maintain the erect posture.

Stature. The stature of the American white soldiers and the Negro soldiers at Camp Gordon was higher than at Camp Lee and the index was lower, and the stature of the Manila students was greater than that of the men of Taytay and the index was lower; but on the contrary, the Cainta men of less stature than the Manila students also have a lower index, and the students of the University of Virginia have a lower stature and a lower index than the white soldiers of Camps Lee and Gordon. Differences in the proportions of the anatomical types in the different groups explain the differences in index. For instance there are more hyper-ontomorphs ${ }^{1}$ among the men of Cainta than among the men of Taytay and there are more hyper-ontomorphs among the students than among the white soldiers. The hyper-ontomorphs have a low index and this makes the index of the Cainta men and the students low.

Sex. The women of Taytay have the lowest stature, but the index is the same as that of the Virginia University Professors who have almost

${ }^{1}$ For explanation of these terms see author's other publications. 
the highest stature. The women have a larger proportion of the hypoontomorph type among them than the men, and this would account for some difference, but there is also a sexual difference: the women have in general relatively longer trunks than men. The Negrito blood of the Taytay women would give a low index, and the Chinese blood would give a high index, but the low stature, the hypo-ontomorph type and the sex would combine to make the index high.

\section{SUMMARY}

The sitting height index is shown to vary with race, type, stature and sex.

The index is the same in the American white and the Filipino, but less in the Negro. The trunk of the Negro is greatly curved thus making it both absolutely and relatively short, which with relatively long legs accounts for the low index in this race.

The index decreases with increase in stature. The American white is taller than the Filipino and therefore should have a smaller index, but the Filipino has a considerable amount of Negrito blood, and a large amount of the hypo-ontomorph type, which reduce his index to the level of that of the white American.

The index is greater in the female than in the male. The number of hypo-ontomorphs was 50 per cent greater among the females than among the males under observation, and the stature of the females was less than that of the males. The sex difference is a result of type, stature and sex.

Finally, the sitting height, and therefore the leg length, are dependent not only on growth but also on metamorphosis.

\section{The Distribution of the Sitting Height}

The materials for part III include the records of many authors, with measurements of more than 200,000 persons, in about 400 groups, of peoples throughout the world.

The three great masses of peoples. In any study of the peoples of the earth it may be well to bear in mind that the three great masses, African, Asiatic-American, and European, represent the fundamental stocks that carry on evolution. Other peoples about the fringes of these great masses, or in isolated regions, such as the Eskimo, Australians, Melanesians, Negritos, and others represent modified peoples through isolation and selection, or mixtures, blends, or mosaics who have undergone various changes. 
The average stature, sitting height and sitting height index for the great continental masses of peoples are given in table 5 .

Table V. The average Stature and Sitting Hight Index for the Fotr Great Masses of Mrn.

\begin{tabular}{|c|c|c|c|c|}
\hline Mass & Stature & $\begin{array}{c}\text { Sitting } \\
\text { height }\end{array}$ & $\begin{array}{c}\text { Sitting height } \\
\text { Index } \\
\end{array}$ & Number \\
\hline \multicolumn{5}{|c|}{ Male } \\
\hline $\begin{array}{l}\text { Asia } \\
\text { America (Indian) } \\
\text { Africa } \\
\text { Europe }\end{array}$ & $\begin{array}{l}165.0 \\
168.0 \\
172.0 \\
165.0\end{array}$ & $\begin{array}{l}88.0 \\
88.0 \\
85.0 \\
87.0\end{array}$ & $\begin{array}{l}53.5 \\
52.3 \\
49.5 \\
52.5\end{array}$ & $\begin{array}{r}1,267 \\
1,050 \\
3,500 \\
165,000\end{array}$ \\
\hline & \multicolumn{2}{|c|}{ Female } & & \\
\hline $\begin{array}{l}\text { America (Indian) } \\
\text { Africa } \\
\text { Europe }\end{array}$ & $\begin{array}{l}157.0 \\
162.0 \\
155.0\end{array}$ & $\begin{array}{l}82.0 \\
80.0 \\
83.0\end{array}$ & $\begin{array}{l}52.6 \\
49.4 \\
53.5\end{array}$ & $\begin{array}{r}500 \\
100 \\
1,500\end{array}$ \\
\hline
\end{tabular}

An effort is made to leave out the peoples along the fringes and to take only records from centrally located groups. This is easy to do for a large part of Asia and means more than for the other continents, because the Chinese are centrally located and have been fairly stable in their territory. America is somewhat like Asia, although movements have been common and the American Indians are comparatively recent entrants. They have however become isolated and are therefore best given apart. Africa, in the north, is a continent of recurring movements of peoples largely from Europe and Asia. The heart of the continent has not been explored nor have the natives of the interior been measured, to a sufficient extent, therefore most of the available records will be those of Negroes mixed more or less with whites. Europe has had interminable intermingling of peoples, but they have been mostly of the same or similar stocks.

From table 5 it will be seen that Asia and Europe have on the whole the same stature, while that of America is higher, and that of Africa still higher. The Negroes measured were chiefly impure stocks such as the Nilotic, Nigerian, Bantu and American. America and Asia have the same sitting height, that of Europe is less and that of Africa is still less. Asia has the highest sitting height index, that of Europe is next, that of the American Indian is close to that of Europe, but that of the Negro is far lower than the others. 
Outlying groups of peoples. When we examine the sitting height index for outlying groups as illustrated in table 6 , we find the lowest index among the Australians and the highest among the Eskimo. Closely related to the Australians are the Negroes, Negritos, and Melanesians, while closely related to the Eskimo are the Siberians, Chinese, and Aino. A low index relates to the Negroes and a high index relates to peoples of low stature who live under adverse conditions.

Table VI. The Sitting Height Index of Selected Grodps.

\begin{tabular}{|c|c|c|c|c|}
\hline \multirow[t]{2}{*}{ Grour } & \multicolumn{2}{|c|}{ MALE } & \multicolumn{2}{|c|}{ FEMALE } \\
\hline & No. & Index & No. & Index \\
\hline Africa. & 3,884 & 49.9 & 185 & 50.3 \\
\hline Europe.. & 8,499 & 52.4 & 1,346 & 53.1 \\
\hline Asia (Chinese). & 1,429 & 53.6 & 25 & 53.0 \\
\hline Other Asiaties. . & 158 & 52.4 & 46 & 52.4 \\
\hline South America (Indian). & 2,812 & 52.4 & 756 & 53.2 \\
\hline North America (Indian) & 1,398 & 52.0 & 494 & 52.1 \\
\hline Eskimo . . . . . . . . . & 94 & 53.7 & 74 & 54.6 \\
\hline Siberians........... & 1,417 & 53.5 & 72 & 53.5 \\
\hline Aino. . & 90 & 52.8 & 71 & 53.6 \\
\hline Malay... & 1,417 & 52.1 & 125 & 52.0 \\
\hline India......... & 598 & 51.6 & $\ldots$ & $\ldots$ \\
\hline African Pigmies... & 49 & 53.7 & 16 & 52.9 \\
\hline Negritos.......... & 378 & 50.9 & 10 & 49.8 \\
\hline Melanesians & 200 & 50.0 & 10 & 51.3 \\
\hline Central Africans & 226 & 47.4 &. & $\ldots$ \\
\hline Australians... & 40 & 45.5 & 10 & 47.9 \\
\hline
\end{tabular}

When we combine the groups in table 6 with those in table 8 it will be noted that the sitting height index of the Negroes of central Africa is 47.4 and that of the Australians is 45.5. This index changes gradually through the Melanesians, 50.0, and Negritos, 50.9, to the East Indians, 51.6, and Malays, 52.1. In each group the Negro influence is distinct and in diminishing amount. The index of the Eskimo is 53.7, and the index drops gradually through the Siberians, (male 53.5, female 53.5), to the Chinese, (male 53.6, female 53.0). The African Pigmies, (male 53.7, female 52.9), and the Aino, (male 52.8, female 53.6), are similar to the Eskimo in the index, and represent isolated fragments of the Negro and mixed stocks in the same way that the Eskimo represent isolated fragment of the Asiatic stocks.

The tropical forest people, especially the Pigmies of Africa and the Indians of the Amazon basin, have not only the handicaps of luxuriant 
vegetation which prevents agriculture, few domestic animals, tough grass, insect pests, rusts, blights, and bacterial infections, but to these must be added the natural aversion to labor and lack of energy on account of the disadvantages of the tropical climate. The frozen desert people of the north such as the Eskimo, Northern Siberians and Lapps, labor under disadvantages of slight rainfall, scanty vegetation, practically no agriculture, few animals and a sparse population. The result in either case is a stunted body growth, which through heredity has become more or less fixed. Dr. Donaldson suggests that the large torso and short extremities allow a relatively larger set of vital organs that make the people more vigorous, hardy, and resistant to adverse conditions. The extreme forms of this type are found in tropical forest and cold desert, but other peoples adjacent to them are similar in type and among all peoples sporadic cases occur, and variants that approach that type. On the other hand are people who are the direct reverse, and between the two may be found endless intergrades.

A few notes about the Pigmies may not be out of place here. Poutrin describes two or more types of Pigmies in Africa. The Ba-Binga, or true Pigmy, is small, 150 centimeters in stature, muscular, with long torso, high large pelvis, short legs, long arms, low cranium, large nose (straight and wide), feeble prognathism, and projecting chin. The BaTua is a Negro model reduced, with all the Negro characteristics except size: small, 150 centimeters and over in stature, thin, with short torso, long legs, small, low pelvis, high cranium, low, broad, depressed nose, considerable prognathism and reduced chin. The sitting height index of the males and females of the two classes are given in table 7.

Table Vil. The Statdre and Sitting Height Index of African Pigmies, Ba-Binga, Poutrin.

\begin{tabular}{lrrrrrr}
\multicolumn{1}{c}{ Group } & No. & $\begin{array}{c}\text { MaLE } \\
\text { Stature }\end{array}$ & Index & No. & $\begin{array}{c}\text { FEMaLE } \\
\text { Stature }\end{array}$ & Index \\
\hline Labaye & 9 & 148.6 & 54.3 & 7 & 143.5 & 53.1 \\
N'Gali & 8 & 148.0 & 55.5 & 5 & 144.3 & 53.3 \\
Ouesso & 4 & 151.2 & 53.3 & & & \\
N'Gongo & 4 & 154.0 & 52.0 & & & \\
M'Bio & 12 & 155.1 & 53.2 & 4 & 154.7 & 51.5 \\
Gondicola & 12 & $\mathbf{1 5 8 . 4}$ & 52.8 & & & \\
\hline
\end{tabular}

As the sitting height index decreases and the stature increases, the form becomes more like the true Negro. The pure Ba-Tua are in this respect intermediate between the Ba-Binga and the Negroes. This 
refers to the "type sousdolichocéphalique" of Poutrin. The "type brachycéphalique" has a stature of approximately 143 centimeters for the male and 137 for the female. This is then a third type, probably more infantile than the Ba-Binga, certainly smaller. The "type sousdolichocephalique" and the Semang have the same stature and the same sitting height index; they are identical in this respect with the Kubus of Sumatra, and not materially different from the Aino. This seems to mean that under adverse environment various peoples may become altered in the same way, becoming more infantile or hypoontomorph in type. The Aino represent probably a mixed group, the Pigmy represents the Negro, the Eskimo represents the northernmost Asiatics, and the Malay represents the much more southern Asiatic, all of the hypo-ontomorph type.

Dr. Hrdlička kindly furnished me with records of the stature and sitting height of 231 adult male and 120 adult female Negritos of the Philippines measured under his direction by Dr. Philip Newton. The stature of the males is $146.8 \mathrm{~cm}$. and the index is 50.6 , and the stature of the females is $138.8 \mathrm{~cm}$. and the index is 51.2 . They are distinctly of the African Negro type. This verifies my own observations of certain Negritos in the Philippines. Other types of Negritos there are of the African Pigmy type. The Senoi or Sakai seem to be mixtures of the Semang and the Malay because the index is the same as the European, identical with the mixed Filipino, and the explanation is that the low index of the Negrito and the high index of the Mongolian neutralize each other and leave the index in between, like that of the European. People who resemble the Senoi or Sakai may be found in all the large islands of the Philippines, especially toward the interior where the Negritos formerly existed.

The sitting height index is shown by Martin to vary in all countries and he gives the lowest index of the male Europeans as 51.4 for the Ukranian Jews, the highest as 53.7 for Esthonians; of the females 53.2 for the Great Russians and 53.7 for the Russian Jews; the lowest index of the male Asiatic as 50.8 for the Malai, the highest as 54.8 for the Aino; of the females as 51.7 for Cambodgia and 54.6 for the Aino; the lowest index of the male African as 48.9 for the Masai, the highest as 54.0 for the Pigmy; of the females as 50.5 for the Bushmen and 53.2 for the Pigmy; the lowest index of the male American natives as 50.6 for the Trumai Indians, the highest as 53.5 for the Eskimo; of the females as 51.1 for the Trumai and 53.7 for the Eskimo. These records of Martin, like those from Giuffrida-Ruggeri, are given without stature and therefore were not used in the tables and charts. 
Giuffrida-Ruggeri gives 30 groups of East Indians of about 100 in each group, from Burma and Bombay which show indices varying from 49.6 to 52.5, suggesting the influence of a Negro stock. The peoples of India are derived from four chief sources, first the Negritos, second Asiatics from the north, third the Mediterraneans, and last the Aryans or Indo-Europeans from northern Europe. There seems to be more Mediterranean stock in the Deccan, and especially among the Todas and Tamils. Twenty groups from the Balkans given by Giuffrida-Ruggeri, with from 12 to 2,341 individuals in each group, give indices varying from 51.8 to 52.6. The low sitting height index goes with the Mediterranean stock and the high index with the Slav. The index of the Spanish is 52.1 and of the Swedes is 52.9, which would indicate the difference we would expect between a small and tall group except that the index is reversed. This emphasizes the difference in type. The Spanish are of the Mediterranean stock and the Swedes of the Nordic, and the inference is that the Nordic is more like the Slav than like the Mediterranean. Six groups from north Nyassa have indices from 49.8 to 51.5, Algerians have an index of 51.7 and Kabyles of 52.8. Here we have the Mediterranean race mixing with the Negro, and in the Kabyles there may be Nordic elements.

Topinard gives six groups of Western European males with indices varying from 52.2 to 52.8, and six other groups from other parts of Europe with indices varying from 51.4 to 54.9. He also gives the index of Australian males as 50.8 .

Baxter and Gould give the perineum-to-sole length of 12,640 white soldiers as 47.5 per cent of the stature which would give an approximate sitting height index of 52.5. In 2,020 Negroes this was near 51.5 and in 517 Iroquois, mostly mixed bloods, it was near 53.4 per cent.

Summary of the sitting height in large groups. We may now turn to a more detailed consideration of the sitting height and then give the summary as found in the chief groups of living men. The details may be found in Table 8 arranged in groups by stature. In each stature-group the index is arranged serially, the lowest first and the highest last. More Negro or negroid groups are given in the table than European, Asiatic and all other groups, therefore the records are not fairly representative. The negroid peoples have a low sitting height index, therefore their records will fall near the first of each stature group, and the Asiatic, American Indian and European will be found in the second half. The Pigmies, Siberians, Aino and other peoples of stunted growth have the highest indices in the low stature groups, and the Europeans and American Indians have the highest indices in the high stature groups. 
The records from table 8 (see end of article) are utilized for the great continental masses of peoples, each of which below will be presented separately, beginning with Europe.

\section{EUROPE (AND AMERICA)}

The median index of the male is 52.3 , the lowest is 51.4 in Little Russians and Livonians, and the highest 53.7 in Esthonians. The majority of the groups of the European males are found between 160 and $180 \mathrm{~cm}$. in stature, and of the females between 150 and $160 \mathrm{~cm}$. The 119,571 Spaniards and the 44,929 Swedes (Giuffrida-Ruggeri) have respective indices of 52.1 and 52.9 , which would indicate that the body type of the two is somewhat different.

\section{AFRICA}

The median index of the male is 50.0, the lowest is 47.4 in Central Africa, and the highest is 55.5 in the Pigmy. The extremes are much further apart than for any other great mass of peoples (unless we include the Pacific Islanders as a great mass), as a result not only of diversity of environment, but also owing to differences of type and variety of mixture. The highest index is found in the Pigmies, and the lowest in Central Africa as already noted, but the tall negroes who surround the central part of the continent of Africa, and especially the Nigerians, Soudanese, Nilotic and Bantu-Kaffir-Zulu Negroes have a low index although they show varying amounts and kinds of mixture with foreign stocks, chiefly European. These Negroes are found in the stature group 180 to $190 \mathrm{~cm}$. and a part at least of their small index is the result of the tall stature. The true Negro of Central Africa is not tall, but has relatively long extremities and a short torso, and some of these characteristics are retained in the tall Negro. The Pigmy, by contrast with the tall Negro and the true Negro has a stunted growth with retention of the infantile characters, the extreme form of the hypo-ontomorph, therefore the index is high.

Had more true Negroes been included in the records and fewer of the Pigmies and tall Negroes, the stature groups would have been less extended and more intermediate. As it is the large majority lie in the same stature groups as the Europeans, between 160 and $180 \mathrm{~cm}$. The stature groups of the African females are the same as those of the European females, but the index is much less. 


\section{OCEANIC NEGROIDS}

The median index of the male is 50.5, the lowest is 44.2 in Australia, and the highest is 52.8 among the Sakai. The index would be considerably lower if the groups mixed with Malay or Asiatic were excluded. Lower indices are found among the Australians than among any groups in Africa and the stature is also lower. The length of the torso and the lower extremities are further apart among the Pacific Islanders than among Africans because of the lower index of the Australians and the higher index of the Mongoloid elements and Pigmy Negritos. The low index among the Australians diminishes through the Melanesians, Negritos and Sakais, to the Malay, although some of the groups among the Malays are very negroid and much like the Negrito. The majority of the stature groups of the male Pacific Negroids are found between 160 and $170 \mathrm{~cm}$. The stature groups of the female Pacific Negroids are found between 140 and $160 \mathrm{~cm}$. which is the same as the Malays and Asiatics, but is different from the Europeans, Africans and American Indians.

MALAYS

The median index of the male is 52.3 , the lowest is 48.6 in the Singalese, and the highest is 53.4 in the Filipinos. There is not an orderly decrease in the index with increase in stature as in the other groups, and the reason for this is that the Malays are very much mixed as noted before. The mainland in India and the Malay Peninsula, as well as the large islands of the Pacific near the mainland and not far from Australia, such as Ceylon, Sumatra, Java, Borneo and several of the Philippines retain evidence of Negrito or Negro influence, and remnants of Negrito tribes may be found in most if not all of the islands. This invariably gives a low sitting height where the type is like the African Negro, but where the type is like the Pigmy or when mixed with the Asiatic the index is high. The stature is low because both the Negrito and the southeastern Asiatic have low stature. Some of the tribes of the interior of the large islands, such as the Kalingas of northern Luzon who are practically pure Europeans in type have tall statures which may be as high as $180 \mathrm{~cm}$. or higher.

\section{ASIA INCLUDING THE AINO}

The index of the male and female is the same even with different statures. The median index of the male is 53.2, the lowest is 50.8 in India, and the highest is 54.1 in Samoyeds. The low index of India is the result not only of the Negrito influence but also of the Mediter- 
ranean, which is profusely distributed throughout India. The high index of Siberia and southeast Asia (Annam, for example) is the result of the type of infantile form, the hypo-ontomorph. The males have a homogeneous, intermediate stature, and the index is practically the same in the two stature groups, 53.2. The stature of the females is also homogeneous, but rather small. The index is practically the same as that of the males, except that the Aino has a higher index, 53.7.

\section{AMERICAN INDIANS AND ESKIMO}

The median index of the males is 52.5 , the lowest is 50.1 for the Machiganga of South America, and the highest is 54.9 for the Kwakiutl of Canada; and for females the median is 52.8, the lowest 51.1 in the Maricopas, and the highest is 55.7 among the Eskimos. The Canadians have an index in the female of 55.4 in one group. The Canadian Indians are similar to the Eskimos in this respect and not unlike the Siberians. A number of groups of Indians in South America and Central America besides the Machiganga have low indices, such as the Arowaks; but the Pimas, Papagos and Sioux also have low indices by some authors, although the stature is high, or because the stature is high. This may point to Negro mixture in some cases or it may be on account of local conditions and stature.

The stature of the American Indian males lies nearly all below 170 $\mathrm{cm}$. which is like that of the European males. The females have a stature chiefly between 150 and $160 \mathrm{~cm}$.

\section{GENERAL SUMMARY}

The sitting height depends upon age, stature, sex, race and type, as well as evolution, environment and individual development, and in any consideration of this measured part of the body all of the factors should be known.

AGE

The sitting height grows more rapidly during and after puberty than before. It remains stationary between 25 and 60 years and decreases thereafter. Girls are precocious and boys retarded in the growth of the sitting height.

THE MORPHOLOGIC INDEX

This index is devised as a factor which represents the percentage difference, of any group, person, type, index or measurable character, from a standard selected as the approximate general norm or average. 
The norm should be as near the average for mankind as a whole, as it is possible to reach with our present state of knowledge.

We may use stature to illustrate. Taking the mean standard stature as 165 centimeters, then a person, type or group of people with a stature of 181.5 centimeters would have a morphologic index of +10 , and a person, type or group of people with a stature of 148.5 centimeters would have a morphologic index of -10 . The morphologic index is +10 because the stature is 10 per cent above the normal standard, and the index is -10 because the stature is 10 per cent below the normal standard.

From a study of all peoples it seems expedient to adopt here a normal standard for stature, sitting height and sitting height index, that may serve as a basis for computing the morphologic index. This standard will be adopted chiefly on the basis of the European records, and as far as the stature is concerned it is the same as that generally used by anthropologists as the central norm about which all the statures of the world may be most conveniently grouped. The standards adopted are: For males: Stature, $165.0 \mathrm{~cm}$., Sitting height $85.0 \mathrm{~cm}$., Sit. Ht. Ind. 52.5; For females: Stature, $155.0 \mathrm{~cm}$., Sitting height, $80.0 \mathrm{~cm}$. Sit. Ht. Ind. 53.5 .

The morphologic index has been calculated for all the groups on which there are sufficient data, and the results have been combined and illustrated in charts V, VI, and VII.

In chart $V$ the most distinctive characteristic of the morphologic index for stature is the low index for Central America and the Pacific.

In chart VI for sitting height the morphologic index is seen to be high in Europe, Asia and North America, and low for Central America.

In chart VII for the sitting height index the morphologic index is high for Asia and extremely low for Africa.

\section{TYPE}

Where short legged people live, conditions of life are difficult. The two great areas occupied by these people are tropic and arctic desert, where only with difficulty can a meager supply of food be obtained. The result has been that through selection and the survival of the fittest environment has produced a resistant type. By desert is meant jungle and ice of tropic and arctic region respectively.

In a general way we may say that each large group of people has its Hypo-ontomorph, or incompletely metamorphosed form: The Aino for the European; the Siberian, Indo Chinese and Malay for the Asiatic; 
the Pigmy and Negrito for the African; and the Eskimo for the American Indian. These forms do not represent those who have failed to develop

Morphologic Index of Stature

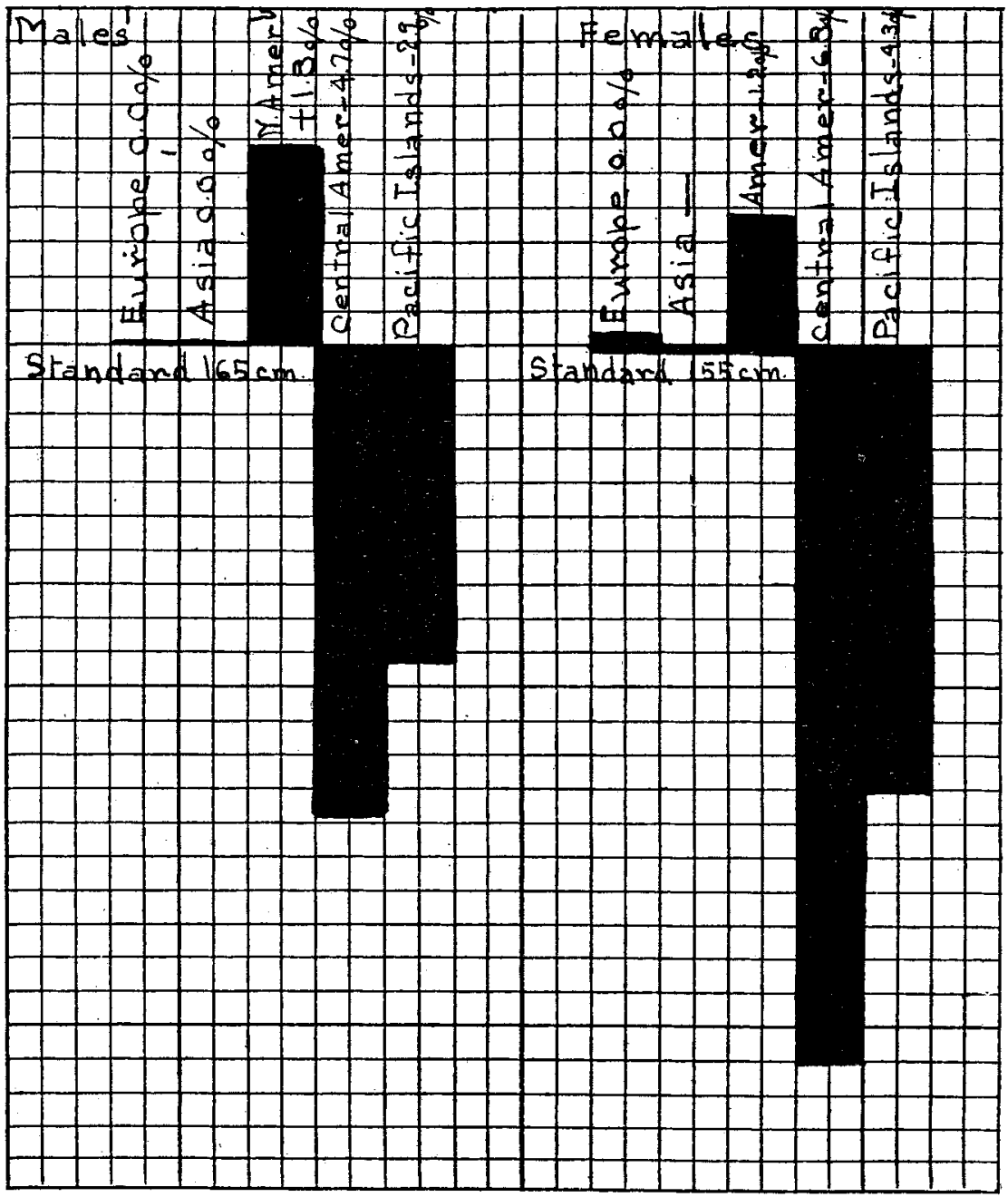

Chart V

through evolution but a regressive condition probably caused by the adverse environment.

At the other extreme are to be found certain groups that seem to have undergone excessive metamorphosis. Such are the Mediterranean for 
the European, the Japanese for the Asiatic, and the long legged Negrito for the African. These are the extreme Hyper-ontomorph types of the stock to which they belong.

The Hypo-ontomorph may be looked upon as the type which metamorphoses so slowly that growth is completed before complete metamorphosis is reached, and the Hyper-ontomorph metamorphoses so

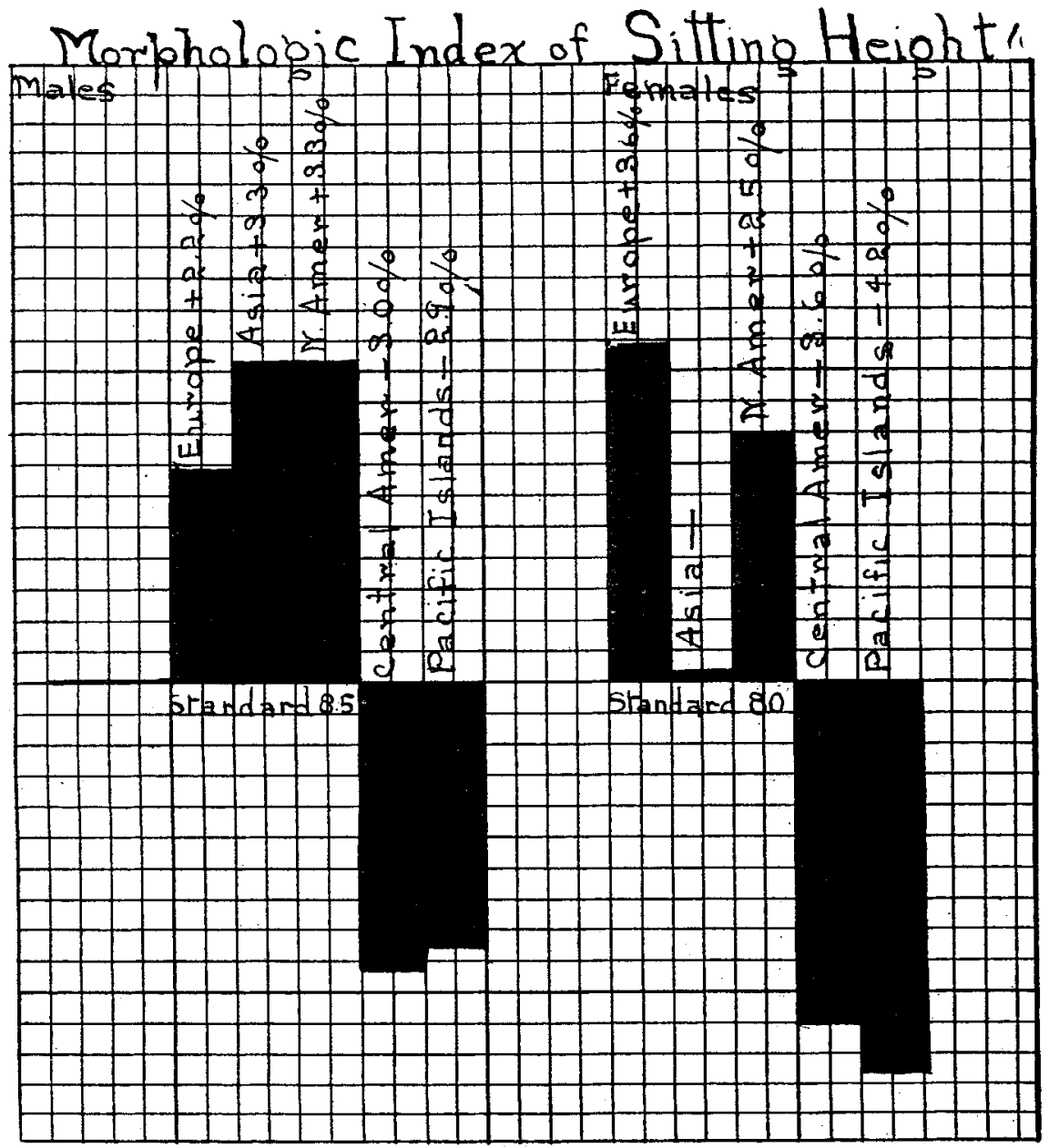

Chart VI

rapidly that growth is incomplete when complete metamorphosis is reached, at which time growth ceases. Growth is less in either case than with intermediate forms. Between these two extremes lies the great 
body of each continental mass, which is the Meso-ontomorph of the stock. This mass carries that from which future variants may spring, under varying conditions. Intergrades may become distinct through segregation and environmental conditions. A combination of inter-

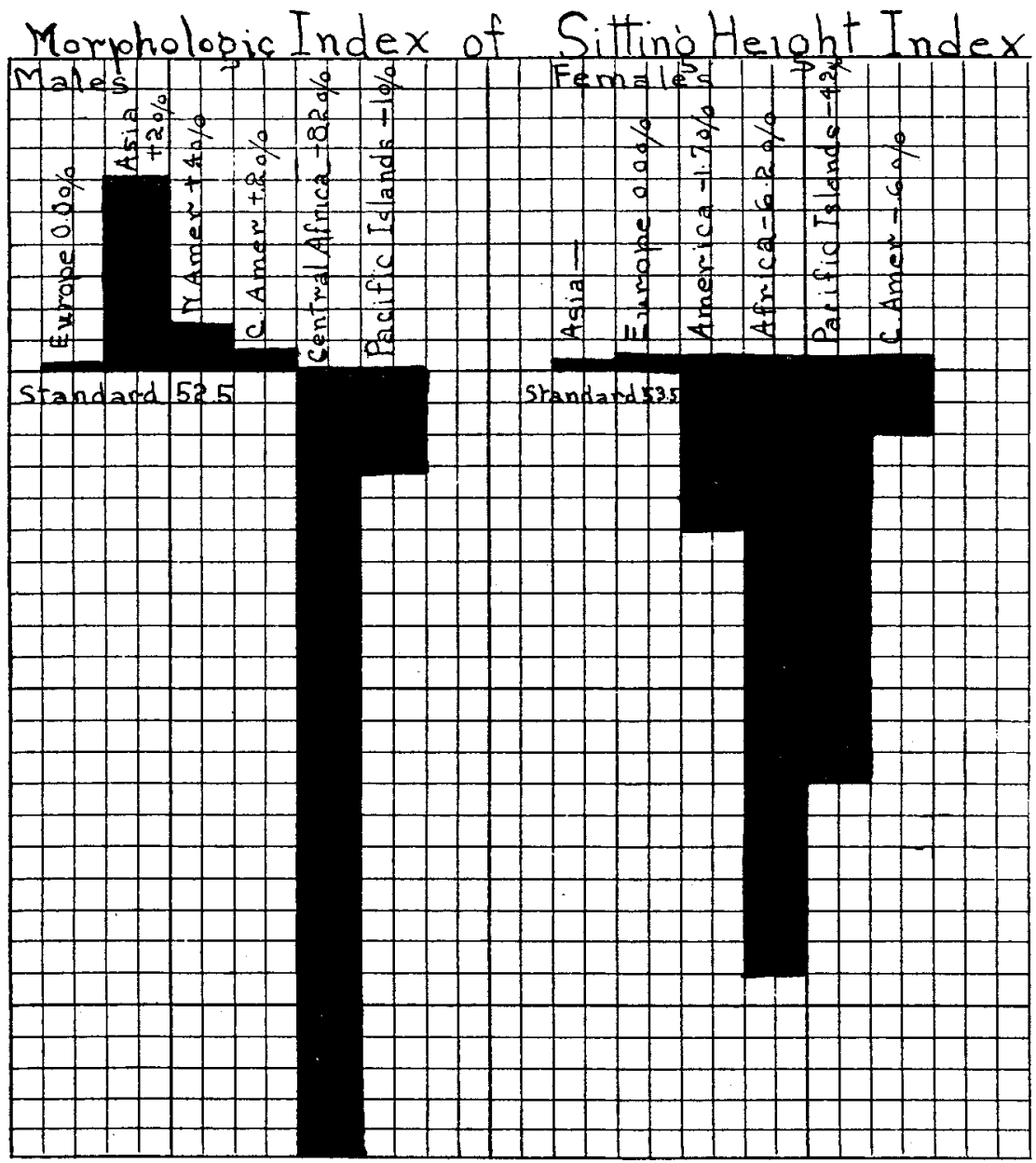

Chart VII

grades may produce many varieties through crosses that result in mixtures, blends, impure or incomplete segregates, mosaics and composites.

The Asiatic has the sitting height accelerated early and retarded late in growth, the growth of the sitting height in the African is late and short, and the European is in between. 
RACE

The Asiatic has a long torso and short extremities, the African has a short torso and long extremities, and the European is in between.

Race movements have altered the stock. There are two areas of extremely low sitting height, Central Africa and Australia, and radiating from these areas the sitting height increases. There are two centers of high sitting height, tropical and arctic, where people live under adverse environment.

\section{STATURE}

The sitting height is inverse to the stature: with small stature the sitting height is relatively great and with a large stature the sitting height is relatively less, within the race. Between races this is not true. The Negro, regardless of stature, has a lower sitting height than any other people.

The sitting height index is a percentage of the stature. When the type is Hyper-ontomorph the index is low and when the type is Hypoontomorph the index is high. It is greater in the female than the male, even when they are of the same type and stature.

\section{CONCLUSIONS}

In any evaluation of the sitting height five factors should be known: Age, sex, race, type, and stature.

Sexual, racial and type differences appear during growth, and continue in the adult.

Racial differences that remove the Negro further from the remainder of mankind than any other group of people have been demonstrated.

Differences as the result of environment through isolation and selection appear.

Differences as the result of stature both during growth and in the adult and in races are evident.

The activities of the hormones may aid in the solution of the relations of the growth and metamorphosis of the torso and the extremities, and thus help to an understanding of problems brought out by a study of the sitting height, after we have learned more about the activities of the hormones. The thyroid gland is known to accelerate metamorphosis, therefore the Hyper-ontomorph may be looked upon as the result of high thyroid activity. The lack of thyroid activity or high thymus activity may be present in the Hypo-ontomorph, as in achondroplastic dwarfs. The gonads and the hypophysis play a rôle in determining the 
ultimate size and sexual characteristics of the body. The interactions of the endocrine glands may be the key to the differences in type, in sex and in race.

Table VIII.

Males. Stature, 140.0 to 149.9 CENTIMEters.

\begin{tabular}{|c|c|c|c|c|c|}
\hline Number & Group & Stature & $\begin{array}{l}\text { Sitting } \\
\text { height }\end{array}$ & $\begin{array}{l}\text { Sitting } \\
\text { height } \\
\text { Index }\end{array}$ & Author \\
\hline 5 & Sakai & 149.1 & 67.4 & 49.7 & Duekworth \\
\hline 231 & Negrito & 146.8 & 74.3 & 50.6 & Newton (Hrdlička) \\
\hline 34 & German & & & 53.1 & Pfitzner \\
\hline 26 & Filipino & 149.7 & 79.9 & 53.4 & Bobbitt \\
\hline 9 & Pigmy & 148.6 & 80.7 & 54.3 & Poutrin \\
\hline 8 & Pigmy & 148.0 & 82.2 & 55.5 & Poutrin \\
\hline
\end{tabular}

MALES. STATURE, 150.0 TO 159.9 CENTIMETERS.

\begin{tabular}{r|l|r|r|l|l}
6 & Toureg vassals & 158.5 & 77.5 & 48.8 & Verneau \\
14 & Bushmen & 155.3 & 77.0 & 49.5 & Werner \\
119 & Niger & 159.4 & 81.0 & 50.8 & Tremearne \\
18 & Machiganga & 155.9 & 78.1 & 50.1 & Ferris \\
7 & Borneo & 156.0 & 79.5 & 50.9 & Rose \& McDougal \\
6 & Balek Papau & 153.6 & 78.3 & 51.0 & Garrett \\
72 & Bushmen & 156.4 & 80.0 & 51.0 & Seiner \\
10 & Kanikar & 153.6 & 78.7 & 51.2 & Schmidt \\
16 & Arawaks & 155.0 & 79.2 & 51.2 & Ten Kate \\
3 & & & & & \\
tribes & Arawaks & 159.4 & 81.8 & 51.4 & Farrabee \\
10 & Eskimo & 157.7 & 81.1 & 51.4 & Duckworth \\
11 & Pulayar & 157.8 & 81.2 & 51.5 & Schmidt \\
42 & Borneo & 157.3 & 81.0 & 51.5 & Rose \& McDougal \\
30 & Kurumbar & 156.3 & 80.7 & 51.6 & Schmidt \\
94 & Borneo & 155.8 & 80.5 & 51.6 & Rose \& McDougal \\
49 & Borneo & 158.9 & 82.0 & 51.6 & Rose \& McDougal \\
& Ba Tua & 152.2 & 78.8 & 51.8 & Poutrin \\
5 & Ulladem & 151.5 & 78.6 & 51.8 & Schmidt \\
13 & Borneo & 153.9 & 79.7 & 51.8 & Rose \& McDougal \\
14 & Irular & 155.4 & 80.7 & 51.9 & Schmidt \\
4 & Pigmy & 154.0 & 80.1 & 52.0 & Poutrin \\
6 & Bulangen & 157.8 & 82.0 & 52.0 & Garrett \\
37 & Malay Pen. & 158.4 & 82.4 & 52.0 & Annandale \& Robinson \\
37 & Sundanese & 159.1 & 83.0 & 52.0 & Garrett \\
10 & Quichua (mix.) & 158.0 & 82.2 & 52.0 & Chervin \\
13 & Bushmen & 152.5 & 78.0 & 52.1 & Seiner \\
13 & Semang & 152.4 & 79.7 & 52.2 & Annandale \& Robinson \\
13 & Sakai & 156.3 & 81.5 & 52.2 & Knocker \\
\hline
\end{tabular}


$\mathrm{T}_{\mathrm{ABLE}}$ VIII-continued

\begin{tabular}{|c|c|c|c|c|c|}
\hline Number & Group & Stature & $\begin{array}{l}\text { Sitting } \\
\text { height }\end{array}$ & $\begin{array}{l}\text { Sitting } \\
\text { height } \\
\text { Index }\end{array}$ & Author \\
\hline 5 & Malay & 153.1 & 79.8 & 52.2 & Schmidt \\
\hline 78 & Jews & 159.4 & 83.3 & 52.2 & Weissenberg \\
\hline 21 & Kota & 159.8 & 83.6 & 52.3 & Schmidt \\
\hline 2,276 & $\begin{array}{l}\text { Mex. \& C. Amer. } \\
\text { Indian }\end{array}$ & 157.5 & 82.6 & 52.4 & Starr \\
\hline 33 & Dyaks & 157.0 & 82.5 & 52.5 & Knocker \\
\hline 80 & Quichua & 158.4 & 83.0 & 52.5 & Ferris \\
\hline 17 & Javanese & 157.1 & 82.5 & 52.5 & Garrett \\
\hline 6 & Bugis & 154.4 & 81.2 & 52.6 & Knocker \\
\hline 183 & Filipinos & 159.5 & 83.8 & 52.6 & Bean \\
\hline 277 & German & & & 52.6 & Pfitzner \\
\hline 25 & Fuegians & 157.7 & 83.0 & 52.7 & Hyades \& Deniker \\
\hline 10 & India & 158.1 & 83.3 & 52.7 & Hagen \\
\hline 12 & Pigmy & 158.4 & 83.5 & 52.8 & Poutrin \\
\hline 26 & Sakai & 152.3 & 80.5 & 52.8 & Annandale \& Robinson \\
\hline 90 & Aino & 156.8 & 83.0 & 52.8 & Koganei \\
\hline 124 & Quichua & 158.3 & 83.7 & 52.8 & Ferris \\
\hline 13 & Spuzzurn & 159.7 & 84.5 & 52.8 & B. A. A. S. \\
\hline 10 & Shuswap & 155.4 & 82.4 & 52.9 & B. A. A. S. \\
\hline 75 & Voguls & 156.7 & 82.9 & 52.9 & Rudenko \\
\hline 24 & Quichua & 158.7 & 84.0 & 53.0 & Ferris \\
\hline 67 & Quichua & & & 53.0 & Chervin \\
\hline 10 & Harrison Lake & 158.0 & 84.0 & 53.1 & B. A. A. S. \\
\hline 12 & Pigmy & 155.1 & 82.5 & 53.2 & Poutrin \\
\hline 4 & Pigmy & 151.2 & 80.6 & 53.3 & Poutrin \\
\hline 127 & Ostiaks & 156.5 & 83.6 & 53.3 & Rudenko \\
\hline 5 & "Mallasque" & 154.2 & 82.7 & 53.7 & Rivet \\
\hline 53 & Samoyeds & 156.8 & 84.8 & 54.1 & Rudenko \\
\hline 17 & Aymara & 156.4 & 85.0 & 54.6 & Forbes \\
\hline 104 & Aymara & 159.7 & 87.6 & 54.8 & Chervin \\
\hline \multicolumn{6}{|c|}{ Males. STATURE, 160.0 TO 169.9 CENTIMETERS. } \\
\hline 19 & Australia & 166.4 & 77.5 & 46.8 & Spencer \& Gillen \\
\hline 16 & Singalese & 160.5 & 78.0 & 48.6 & Deschamps \\
\hline 95 & Kanembu & 167.6 & 82.0 & 49.0 & Gaillard \& Poutrin \\
\hline 55 & Oulad-Shinon & 169.3 & 83.1 & 49.1 & Gaillard \& Poutrin \\
\hline 19 & Papuan & 165.6 & 81.6 & 49.2 & Chalmers \\
\hline 20 & Papuan & 163.6 & 80.7 & 49.3 & Chalmers \\
\hline 33 & Teda & 169.6 & 84.0 & 49.6 & Gaillard \& Poutrin \\
\hline 16 & Papuan & 167.7 & 84.0 & 49.9 & Spencer \& Gillen \\
\hline 14 & Papuan & 162.8 & 81.4 & 50.0 & Hagen \\
\hline 82 & Amboras & 168.6 & 84.3 & 50.1 & Verneau \\
\hline
\end{tabular}


TABLE VIII-continued

\begin{tabular}{|c|c|c|c|c|c|}
\hline Number & Group & Stature & $\begin{array}{l}\text { Sitting } \\
\text { height }\end{array}$ & $\begin{array}{l}\text { Sitting } \\
\text { height } \\
\text { Index }\end{array}$ & Author \\
\hline 44 & M'Baka & 167.1 & 84.2 & 50.4 & Poutrin \\
\hline 15 & Papuans & 160.9 & 81.0 & 50.4 & Schellong \\
\hline 18 & Bondjio & 163.0 & 82.5 & 50.6 & Poutrin \\
\hline 25 & Ba-Téké & 162.1 & 82.5 & 50.7 & Poutrin \\
\hline \multirow[t]{2}{*}{77} & Pima & 169.6 & 86.0 & 50.7 & Ten Kate \\
\hline & Arawaks & 161.5 & 81.8 & 50.7 & Farrabee \\
\hline 25 & Somali & 165.5 & 84.5 & 50.8 & Puccioni \\
\hline 27 & Malser & 162.1 & 82.5 & 50.8 & Schmidt \\
\hline \multirow[t]{2}{*}{44} & Tamil & 161.8 & 82.0 & 50.8 & Hagen \\
\hline & Batua & 160.1 & 81.8 & 51.0 & Poutrin \\
\hline 583 & Amer. Negro & 169.7 & 86.6 & 51.0 & Bean \\
\hline 18 & Papago & 169.6 & 86.6 & 51.1 & Ten Kate \\
\hline 57 & Porto Rico & 168.7 & 86.3 & 51.2 & Boas \\
\hline 28 & Badaga & 163.9 & 83.8 & 51.2 & Schmidt \\
\hline 20 & Schonar & 166.2 & 85.0 & 51.2 & Schmidt \\
\hline 150 & Egypt & 163.4 & 84.1 & 51.3 & Hrdlička \\
\hline 54 & Kaffirs & 166.2 & 85.3 & 51.4 & Suk \\
\hline 32 & Papuans & 160.6 & 82.5 & 51.4 & Schellong \\
\hline 200 & Little Russian & 166.9 & 85.2 & 51.4 & Diebold \\
\hline 13 & Melanesians & 163.3 & 84.0 & 51.4 & Hagen \\
\hline 9 & Melanesians & 161.7 & 82.5 & 51.4 & Hagen \\
\hline 105 & Javanese & 160.4 & 82.5 & 51.5 & Kohlbrugge \\
\hline 28 & Pariah & 162.5 & 83.7 & 51.5 & Schmidt \\
\hline 22 & Toda & 169.0 & 87.2 & 51.6 & Schmidt \\
\hline 30 & Tatars & 164.2 & 85.0 & 51.6 & Benzengue \\
\hline 100 & Jews & 162.8 & 84.2 & 51.6 & Blechman \\
\hline 99 & Zapotec & 160.5 & 83.0 & 51.6 & Starr \\
\hline 15 & Lolas & 162.5 & 83.5 & 51.6 & Delisle \\
\hline 27 & Malay & 160.0 & 83.0 & 51.6 & Hagen \\
\hline 67 & Berbers & 164.3 & 85.2 & 51.7 & Topinard \\
\hline 100 & Paris insane & 165.0 & 85.4 & 51.7 & McAuliffe \\
\hline 304 & East India & 161.9 & 83.6 & 51.7 & Schmidt \\
\hline 17 & Brahman & 162.6 & 84.4 & 51.8 & Schmidt \\
\hline 23 & Wellala & 163.9 & 85.2 & 52.0 & Schmidt \\
\hline 23 & Sudra & 165.9 & 86.2 & 52.0 & Schmidt \\
\hline 100 & Jews & 165.1 & 86.0 & 52.0 & Weissenberg \\
\hline 100 & Tarasean & 160.0 & 83.2 & 52.0 & Starr \\
\hline 15 & Nkamtúnemuq & 165.7 & 86.3 & 52.0 & B. A. A. S. \\
\hline 12 & Lilloet & 162.3 & 84.5 & 52.0 & B. A. A. S. \\
\hline 127 & Russians & & & 52.0 & Mainow \\
\hline 11 & Melanesians & 161.7 & 84.0 & 52.0 & Hagen \\
\hline 18 & Ntlakyapamuq & 162.7 & 84.7 & 52.1 & B. A. A. S. \\
\hline 780 & Tsiganes & 164.9 & 86.6 & 52.1 & Pittard \\
\hline
\end{tabular}


TABLE VIII-continued

\begin{tabular}{|c|c|c|c|c|c|}
\hline Number & Group & Stature & $\begin{array}{l}\text { Sitting } \\
\text { height }\end{array}$ & $\begin{array}{l}\text { Sitting } \\
\text { height } \\
\text { Index }\end{array}$ & Autbor \\
\hline 38 & Filipinos & 160.9 & 84.0 & 52.2 & Bean \\
\hline \multirow[t]{2}{*}{50} & French Lorraine & 169.6 & 88.4 & 52.2 & Collignon \\
\hline & Jews (London) & 165.1 & 86.3 & 52.2 & Jacobs \& Spielman \\
\hline 105 & Shoshonean & 166.1 & 86.7 & 52.2 & Boas \\
\hline 7 & Batavian & 163.4 & 85.5 & 52.3 & Garrett \\
\hline 100 & Balkans & 163.5 & 85.5 & 52.3 & Pittard \\
\hline 100 & French & 166.0 & 86.8 & 52.3 & Collignon \\
\hline 100 & Normandy & 168.1 & 88.0 & 52.3 & Garnier-Moronval \\
\hline 38 & Shuswap & 165.2 & 86.7 & 52.4 & B. A. A. S. \\
\hline 748 & German & & & 52.4 & Pfitzner \\
\hline 377 & Filipinos & 163.3 & 85.8 & 52.5 & Bean \\
\hline 100 & French & 165.1 & 86.8 & 52.5 & \\
\hline \multirow[t]{2}{*}{33} & Chilcotin & 165.1 & 86.8 & 52.5 & B. A. A. S. \\
\hline & Jews (English) & 163.3 & 85.0 & 52.5 & Jacobs \& Spielman \\
\hline 125 & Greeks & 167.4 & 88.0 & 52.5 & Pittard \\
\hline 100 & French & 164.0 & 86.1 & 52.5 & Collignon \\
\hline 13 & Lolos & 168.4 & 88.5 & 52.6 & Legendre \\
\hline 11 & Eskimo & 167.9 & 88.2 & 52.6 & Boas \\
\hline 2,341 & Tatar & 163.6 & 86.1 & $52.6 ?$ & Pittard \\
\hline 40 & Battaks & 160.0 & 84.2 & 52.6 & Hagen \\
\hline 41 & Malays & 161.5 & 84.8 & $52.6 ?$ & Hagen \\
\hline 29 & Lolos & 167.5 & 88.3 & 52.7 & Legendre \\
\hline 100 & Paris normal & 165.1 & 86.8 & 52.7 & McAuliffe \\
\hline 10 & Sudanese & 160.8 & 84.8 & 52.7 & Hagen \\
\hline 30 & French & 163.6 & 86.3 & 52.7 & Collignon \\
\hline \multirow[t]{2}{*}{10} & Lolos & 166.7 & 88.1 & 52.8 & Legendre \\
\hline & Jews (London) & 163.3 & 86.5 & 52.9 & Jacobs \& Spielman \\
\hline 7 & Amer. Indian & 166.3 & 88.4 & 52.9 & Boas \\
\hline 12 & Lilloet & 164.3 & 87.0 & 52.9 & B. A. A. S. \\
\hline 10 & Sundanese & 161.8 & 85.5 & 52.9 & Hagen \\
\hline \multirow[t]{2}{*}{100} & Balkans & 169.0 & 89.5 & 53.0 & Pittard \\
\hline & Jews (English) & 168.8 & 89.3 & 53.0 & Jacobs \& Spielman \\
\hline 98 & Tungus & 163.1 & 86.5 & 53.0 & Mainow \\
\hline 30 & Thibet & 164.3 & 85.9 & 53.0 & Delisle \\
\hline 117 & Chinese of Annam & 164.6 & 83.6 & 53.1 & Vaillant \\
\hline \multirow[t]{2}{*}{207} & Jakuts & 162.4 & 86.2 & 53.1 & Mainow \\
\hline & English & 169.8 & 90.0 & 53.1 & Galton \\
\hline 90 & Chinese South & 168.5 & 89.7 & 53.2 & Koganei \\
\hline 68 & Bashkiri & 165.7 & 88.2 & 53.2 & Weissenberg \\
\hline 15 & Maschtscherjaken & 163.6 & 87.2 & 53.2 & Weissenberg \\
\hline 60 & Apache & 169.7 & 90.3 & 53.2 & Hrdlička \\
\hline \multirow[t]{2}{*}{12} & Utàmk't & 161.0 & 85.7 & 53.2 & B. A. A. S. \\
\hline & Jews (English) & 160.8 & 85.0 & 53.2 & Jacobs \& Spielman \\
\hline
\end{tabular}


TABLE VIII-continued

\begin{tabular}{|c|c|c|c|c|c|}
\hline Number & Group & Stature & $\begin{array}{l}\text { Sitting } \\
\text { height }\end{array}$ & $\begin{array}{l}\text { Sitting } \\
\text { height } \\
\text { Index }\end{array}$ & Author \\
\hline 49 & Chinese & 161.4 & 86.0 & 53.2 & Hagen \\
\hline 70 & Java & 161.4 & 86.0 & 53.2 & Hagen \\
\hline 51 & Filipinos & 162.1 & 86.7 & 53.4 & Bobbitt \\
\hline 100 & Chinese & 161.1 & 86.2 & 53.4 & Legendre \\
\hline 53 & Balkans & 166.4 & 88.8 & 53.4 & Pittard \\
\hline 307 & Siberia & 164.6 & 88.3 & 53.5 & Paissel \\
\hline 12 & Eskimo & 167.5 & 89.7 & 53.5 & Boas \\
\hline 92 & Kalmucks & 163.1 & 88.0 & 53.5 & Karolew \\
\hline 125 & Armenians & 166.1 & 89.0 & 53.6 & Pittard \\
\hline 942 & Chinese & 167.5 & 89.7 & 53.7 & Koganei \\
\hline 181 & Buriats & 163.1 & 87.5 & 53.7 & Schendrekowski \\
\hline 100 & Esthonians & 164.3 & 88.2 & 53.7 & Gruber \\
\hline 20 & Nass River & 167.0 & 90.0 & 53.7 & B. A. A. S. \\
\hline 69 & Annam & 162.3 & 87.6 & 53.8 & Roux \\
\hline 24 & Bilqula & 166.0 & 89.6 & 53.8 & B. A. A. S. \\
\hline 150 & Mordvini & & & 53.8 & Mainow \\
\hline 105 & Armenians & 167.1 & 90.5 & 54.1 & Tvarjanovic \\
\hline 61 & Eskimo & 162.7 & 88.3 & 54.3 & Moore \\
\hline 18 & Tinneh & 163.7 & 89.0 & 54.4 & B. A. A. S. \\
\hline 36 & Kwakiutl & 164.4 & 90.2 & 54.9 & B. A. A. S. \\
\hline
\end{tabular}

MALES. STATURE, 170.0 TO 179.9 CENTIMETERS.

\begin{tabular}{r|l|r|r|r|l}
21 & Australia & 172.4 & 76.3 & 44.2 & Spencer \& Gillen \\
141 & Niger & 177.2 & 84.0 & 47.4 & Tremearne \\
85 & Bulala & 175.2 & 83.0 & 47.4 & Couvy \\
25 & Mongawa & 171.0 & 82.0 & 47.9 & Gaillard \& Poutrin \\
30 & Kouri & 173.0 & 83.7 & 48.4 & Gaillard \& Poutrin \\
739 & Niger & 172.1 & 83.5 & 48.5 & Ruelle \\
19 & Toureg & 172.1 & 84.0 & 48.8 & Verneau \\
37 & Niger & 172.1 & 84.5 & 49.2 & Tremearne \\
105 & Bondamme & 173.0 & 85.0 & 49.2 & Gaillard \& Poutrin \\
116 & Niger & 176.0 & 86.5 & 49.2 & Tremearne \\
36 & Toureg nobles & 175.1 & 86.2 & 49.2 & Verneau \\
41 & Dahomey & 176.3 & 87.2 & 49.4 & Verneau \\
16 & Papuans & 170.2 & 84.3 & 49.5 & Chalmers \\
142 & Niger & 173.0 & 86.2 & 49.8 & Tremearne \\
111 & West Africa & 170.0 & 85.7 & 50.4 & Verneau \\
152 & Niger & 170.5 & 86.2 & 50.5 & Tremearne \\
688 & Amer. Negro & 172.9 & 87.2 & 50.5 & Bean \\
29 & Maricopa & 172.2 & 87.8 & 50.8 & Ten Kate \\
& Polynesians & 175.5 & 89.6 & 51.0 & Ten Kate \\
14 & Polynesians & $\mathbf{1 7 2 . 8}$ & 88.2 & 51.0 & Ten Kate \\
\hline
\end{tabular}


TABLE VIII-continued

\begin{tabular}{r|l|r|r|r|l}
\hline \hline Number & \multicolumn{1}{|c|}{ Group } & Stature & $\begin{array}{c}\text { Sitting } \\
\text { height }\end{array}$ & $\begin{array}{l}\text { Sitting } \\
\text { height } \\
\text { Index }\end{array}$ & \\
\hline 100 & Livonians & 173.5 & 89.4 & 51.4 & Waldhauer \\
\hline 536 & Sioux & 172.9 & 88.9 & 51.4 & Sullivan \\
24 & Balkans & 178.5 & 92.0 & 51.6 & Pittard \\
77 & Sioux mix. & 173.5 & 89.3 & 51.6 & Sullivan \\
15 & Tatar & 178.5 & 91.9 & 51.6 & Pittard \\
63 & Kurds & 170.0 & 88.2 & 51.8 & Pittard \\
60 & Lithuanians & 170.5 & 88.8 & 51.9 & Walber \\
295 & German & & & 52.1 & Pfitzner \\
364 & Canada & 170.9 & 88.2 & 52.4 & Pittard \\
2,066 & Amer. white & 174.0 & 91.1 & 52.4 & Bean \\
17 & Amer. Indian & 171.0 & 90.3 & 52.8 & Boas \\
& Jews London & 171.2 & 90.7 & 52.9 & Jacobs \& Spielman \\
35 & Pima Indians & 171.8 & 91.0 & 52.9 & Hrdlička \\
& Old American & 174.3 & 92.3 & 52.95 & Hrdlička \\
& English & 172.5 & 91.5 & 53.0 & Galton \\
& & & & &
\end{tabular}

Males. STATURE, 180.0 To 189.9 Centimeters.

\begin{tabular}{r|l|r|r|r|l}
6 & Niger & 187.1 & 88.0 & 47.0 & Verneau \\
140 & Niger & 184.0 & 90.8 & 49.3 & Tremearne
\end{tabular}

FEMALES. STATURE BELOW 140.0 CENTIMETERS.

\begin{tabular}{r|l|r|r|r|l}
25 & C. Amer. & 139.9 & 76.2 & 54.5 & Starr \\
120 & Negrito & 138.8 & 71.1 & 51.2 & Newton
\end{tabular}

FEMAles. STATURE 140.0 to 149.9 Centimeters.

\begin{tabular}{r|l|l|l|l|l}
3 & Semang & 140.8 & 65.7 & 46.7 & Duckworth \\
1 & Borneo & 148.0 & 71.6 & 48.3 & Rose \& McDougal \\
1 & Borneo & 146.5 & 73.8 & 50.3 & Rose \& McDougal \\
17 & Bushmen & 149.7 & 75.5 & 50.5 & Werner \\
18 & Bushmen & 148.2 & 72.2 & 51.0 & Seiner \\
3 & Borneo & 145.0 & 74.6 & 51.4 & Rose \& McDougal \\
2 & & & & & \\
tribes & Arawaks & 147.9 & 76.5 & 51.7 & Farrabee \\
25 & Dyaks & 145.4 & 75.5 & 51.8 & Rose \& McDougal \\
15 & Machiganga & 143.9 & 74.2 & 51.8 & Ferris \\
6 & Borneo & 149.3 & 77.6 & 51.9 & Rose \& McDougal \\
13 & Ba Tua & 143.7 & 75.4 & 52.5 & Poutrin \\
4 & Sakai & 144.3 & 76.5 & 52.8 & Knocker \\
223 & German & & & 53.0 & Pfitzner \\
63 & Filipino & 147.8 & 78.5 & 53.1 & Bean \\
573 & Mex. \& C. Amer. & 145.3 & 77.2 & 53.1 & Starr \\
\hline
\end{tabular}


TABLE VIII-continued

\begin{tabular}{|c|c|c|c|c|c|}
\hline Number & Group & Stature & $\begin{array}{l}\text { Sitting } \\
\text { height }\end{array}$ & $\begin{array}{l}\text { Sitting } \\
\text { height } \\
\text { Index }\end{array}$ & Author \\
\hline 7 & Pigmy & 143.5 & 76.2 & 53.1 & Poutrin \\
\hline 53 & Fuegians & 147.3 & 78.2 & 53.1 & Hyades \& Deniker \\
\hline 17 & Eskimo & 149.7 & 79.7 & 53.2 & Duckworth \\
\hline 5 & Pigmy & 144.3 & 77.0 & 53.3 & Poutrin \\
\hline 26 & Filipino & 149.7 & 80.0 & 53.4 & Bobbitt \\
\hline 55 & Aino & 146.8 & 78.4 & 53.4 & Koganei \\
\hline 3 & Aino & 142.7 & 77.3 & 54.2 & Koganei \\
\hline 13 & Aino & 149.5 & 81.6 & 54.6 & Koganei \\
\hline 7 & Aymara & 147.8 & 80.6 & 54.6 & Chervin \\
\hline 68 & Quichua & 145.4 & 80.4 & 55.6 & Ferris \\
\hline
\end{tabular}

Females. STAture 150.0 to 159.9 Centimeters.

\begin{tabular}{r|l|r|r|r|l}
17 & Australians & 159.1 & 76.0 & 47.6 & Spencer \& Gillen \\
10 & Australians & 156.8 & 76.0 & 48.4 & Spencer \& Gillen \\
24 & Sioux (old) & 157.7 & 78.8 & 49.9 & Sullivan \\
10 & West Africans & 158.3 & 79.7 & 50.5 & Verneau \\
54 & Negro & 155.7 & 79.0 & 50.8 & Poutrin \\
10 & Polynesians & 159.1 & 81.7 & 51.3 & Ten Kate \\
5 & Papago & 157.6 & 81.0 & 51.5 & Ten Kate \\
51 & Pima & 156.3 & 80.7 & 51.6 & Ten Kate \\
19 & Lilloet & 152.5 & 79.2 & 51.8 & B. A. A. S. \\
12 & Nkamtnemuq & 157.7 & 82.1 & 52.1 & B. A. A. S. \\
30 & Pima & 157.4 & 82.2 & 52.3 & Hrdlička \\
35 & Okanagau & 156.5 & 82.0 & 52.4 & B. A. A. S. \\
62 & Jakuts & 153.4 & 79.5 & 52.4 & Mainow \\
18 & Thibet & 152.6 & 80.0 & 52.4 & Delisle \\
6 & Eskimo & 155.6 & 81.5 & 52.4 & Boas \\
3 & Borneo & 159.5 & 83.8 & 52.5 & Rose \& McDougal \\
14 & Gillooet & 154.2 & 81.1 & 52.6 & B. A. A. S. \\
& Ntlalsyapamupo & 153.0 & 80.7 & 52.7 & B. A. A. S. \\
28 & Shuswap & 155.0 & 81.8 & 52.8 & B. A. A. S. \\
29 & Apache & 157.2 & 83.0 & 52.8 & Hrdlička \\
21 & Shoshonean & 152.8 & 80.8 & 52.8 & Boas \\
430 & Tsiganes & 153.2 & 81.2 & 52.9 & Pittard \\
612 & Germans & & & 52.9 & Pfitzner \\
25 & Chinese & 151.5 & 80.4 & 53.0 & Pyle \\
38 & Balkans & 154.7 & 82.7 & 53.5 & Pittard \\
17 & Utàmk & 153.2 & 81.5 & 53.6 & B. A. A. S. \\
& English & 158.3 & 84.8 & 53.6 & Galton \\
6 & Eskimo & 151.5 & 81.2 & 53.7 & Boas \\
52 & Quichua & 154.1 & 83.2 & 53.8 & Chervin \\
& Jakuts & 150.0 & 72.5 & 54.2 & Mainow \\
\hline
\end{tabular}


TABLE VIII-continued

\begin{tabular}{|c|c|c|c|c|c|}
\hline Number & Group & Stature & $\begin{array}{l}\text { Sitting } \\
\text { height }\end{array}$ & $\begin{array}{l}\text { Sitting } \\
\text { height } \\
\text { Index }\end{array}$ & Author \\
\hline 10 & Tungus & 150.0 & 81.0 & 54.2 & Mainow \\
\hline & Jews English & 152.0 & 82.5 & 54.3 & Jacobs \& Spielman \\
\hline 17 & Nass River Indians & 154.3 & 84.3 & 54.7 & B. A. A. S. \\
\hline 33 & Kwakiutl & 153.7 & 80.7 & 55.4 & B. A. A. S. \\
\hline 46 & Eskimo & 151.7 & 84.6 & 55.7 & Moore \\
\hline
\end{tabular}

FEMALES. STATURE, 160.0 To 169.9 CENTIMETERS.

\begin{tabular}{r|l|l|l|l|l}
33 & Niger & 163.9 & 78.5 & 47.9 & Ruelle \\
18 & Maricopa & 160.1 & 82.0 & 51.1 & Ten Kate \\
44 & Kaffir & 161.0 & 82.6 & 51.4 & Suk \\
156 & Sioux & 160.0 & 82.4 & 51.4 & Sullivan \\
19 & Sioux (mix.) & 161.2 & 82.8 & $\mathbf{5 1 . 4}$ & Sullivan \\
197 & German & 165.0 & 87.0 & 52.6 & Pfitzner \\
& English & 160.8 & 86.1 & 53.5 & \\
200 & Old American & 161.8 & 87.35 & $54 .-$ & Hrdlicka \\
\hline
\end{tabular}

\section{BIBLIOGRAPHY}

Annandale (N.) \& H. C. Robinson-Fasciculi Malayensis. London, 1903.

Bardeen (C. R.)-The Height-Weight Index of Build in Relation to Linear and Volumetric Proportions and Surface Area of the Body During Post-Natal Develop ment. Contributions to Embryology, Carnegie Inst. Wash., 1920, IX, No. 46, 483-554.

Barr (Anne L.) - Some Anthropometric Measurements of Western College Girls. Am. Phys. Educ. Rev., 1903, VIII, 245.

Baxter (J. H.) - Statistics, Medical and Anthropological. Wash., 1875.

Bean (R. B.)-Filipino Types. Philip. J. Sc., 1909, IV, 359-449;--The Racial Anatomy of the Philippine Islanders. Philadelphia, 1909;-The Stature and the Eruption of the Permanent Teeth. Am. J. Anat., 1914, XVII, No. 1, 113-160;Some Characteristics of the External Ear. Am. J. Anat., 1915, XVIII, No. 2, 201-225.

Bent (J. T.)--The Sacred City of the Ethiopians. London, 1893.

Benzengre (B.) - Etude anthropologique sur les Tatars de Kassimoff. Rev. d'Anthrop., 1881.

Blechman (B.)-Ein Beitrag zur Anthropologie der Juden. Dorpat, 1882.

Boas (F.)-A. J. Stone's Measurements of the Natives of the Northwestern Territories. Bull. Am. Mus. Nat. Hist., 1901, XIV, 53-68;-Anthropometry of Shoshonean Tribes. Amer. Anthrop., 1899, N. S., I, 751-758.

Bobbitt (J. F.)-The Growth of Filipino Children. Pedag. Sem., 1909, XVI.

Bowman (E.)-Antiquités de la region Andine de la République Argentine et du desert d'Atacama. Paris, 1908, II, 524.

British A. A. S. Reports On the Northwestern Tribes of the Dominion of Canada. 1892, 1895, 1898. 
Chaillon (A.)-Considération général sur quatre types morphologiques humaines. Bull. \& Mém. Soc. Anthrop., Paris, 1910, Sér. 6, I.

Chalmers (J.)-Toaripi. Anthropometrical Observations on Some Natives of the Papuan Gulf. J. R. Anthrop. Inst., 1898, XXVII, 326-342.

Chervin (A.)-Anthropologie Bolivienne. Paris, 1907, II, 171, 253.

Collignon (R.)-Étude anthropométrique élémentaire des principales races de France. Bull. Soc. Anthrop., Paris, 1883, VI, 463-526.

Corrêa (A. A. Mendes)-Antropologia Angolese. Arch.f. Anat. \& Antrop., 1916, II, No. 4, 323-356.

Couvy (D.)--Notes anthropométriques sur quelques races du territoire militaire du Tchad. L'Anthrop., 1907, XVIII, 549-582.

Crook (A. H.)-Measurements of the Chinese. Nature, 1908.

Delisle (E.) - Sur les charactères physiques des populations du Thibet sud-oriental. Bull. Soc. Anthrop., Paris, 1908, IX, sér. 5. No. 4, 473-485.

Deschamps (E.)-Les Veddas de Ceylon et leur rapports avec les peuples environants, les Rhodias et les Singales. L'Anthrop., 1891, II, 297-337.

Diebold (W.)-Ein Beitrag zur Anthropologie der Kleinrussen. Dorpat, 1886.

Downes (R. M.)-The Interrelationships of Some Trunk Measurements and Their Relation to Stature. J. Anat. \& Physiol., 1914, XLVIII.

Duckworth (W. L. H.)-On the Anthropometric Data Collected by Prof. J. Stanley Gardiner in the Maldine Islands and Minikoi. Proc. Camb. Phil. Soc., 1913, XVII;-An Account of Some Eskimo From Labrador, 1900, X, 286;-Some Anthropological Results of the Skeat Expedition to the Malay States. J. Anthrop Inst., 1902, XXXII, 142-152.

Elderton (Ethel M.)-Height and Weight of School Children in Glasgow. Biometrika, 1914-15, X, 288.

Ethnographic Survey of India. Data from Bombay and Burma. 1906-7.

Ferris (H. B.)-The Indians of Cuzco and the Apurimac. Mem. Am. Anthrop. Ass., 1916, III;-Anthropological Studies on the Quichua and Machiganga Indians. Trans. Conn. Acad. Arts \& Sc., 1921.

Forbes (D.)- On the Aymara Indians of Bolivia and Peru. J. Elhnol. Soc., London, 1870, N. S., II, 193-205.

Fulleborn (F.)-Beiträge zur physichen Anthropologie der Nord-Nyassa-Länder. Berlin, 1902.

Galton (F.)-Some Results of the Anthropometric Laboratory. J. Anthrop. Inst., 1885, XIV, 275-287.

Garnier-Moronval (M.)-Recherches anthropométriques sur les Normands. L'Anthrop., 1913, XXIV, 25.

Garrett (T. R. H.) - The Natives of the Eastern Part of Borneo and Java. $J$. Anthrop. Inst., 1912, XV, 53-63.

Giuffrida-Ruggeri (V.)-Le proporzione del busto nei due sessi e i canon di Fritsch. Atti Soc. Rom. Antrop., 1907, XIII, 45;-Documenti sull indice schelico. Riv. di Antrop., 1916, XX;-L'Indice schelico nei due sessi. Riv. di. Antrop., 1917, XXI.

Gladstone (R. J.)-Brain Weight of Man. Brit. Med. J., 1906.

Godin (P.)-Recherches anthropométriques sur la croissance des diverses parties du corps. 1913;-Les proportions du corps pendant la croissance. Bull. \& Mém. Soc. Anthrop., Paris, 1910;-Lois de croissance. J. Anthrop. Inst., 1914, XLIV, 295-301. 
Gould (B. A.)-Investigations in the Military and Anthropological Statistics of American Soldiers. U. S. Sanit. Comm. Mem., 1869.

Grube (O.)--Anthropologische Untersuchungen an Esten. Dorpat, 1878;Anthrop. Atlas Ostasiatischer und Melanischer Völker. Wiesbaden;-Die Orang Kubu auf Sumatra. Frankfort-am-Main, 1908.

Hagen (B.)--Anthropologische Studien aus Insulinde. Amsterdam, 1890.

Hall (W. S.)--The Changes in the Proportions of the Human Body During Growth. J. Anthrop. Inst., 1896, XXV, 21-46.

Hastings (W. W.)-A Manual for Physical Measurements. Springfield, 1902.

Hitchcock (E.)-Anthropometric Manual of Amherst College, 1900.

Hrdlička (A.)-Anthropological Investigations on One Thousand White and Colored Children of Both Sexes, 1900;-Physiological and Medical Observations among the Indians of Southwestern United States and Mexico. Bull. 84, Bur. Am. Ethnol., 1902;- The Natives of Kharga Oasis. Smithson. Misc. Coll., 1902, 59;Anthropometry. 8 vo., Wistar Inst., Philadelphia, 1921;--Anthropology of the Old Americans. J, Phys. Anthrop., 1922, 1923.

Hyades (P.) and J. Deniker--Mission scientifique du Cap Horn. 1891, VII.

Jacobs (J.) \& I. Spielman-On the Comparative Anatomy of the English Jews. $J$. Anthrop. Inst., 1889-90, XIX, 76-83.

Knocker (F. W.) - The Aborigines of Sungei Ujong. J. Anthrop. Inst., 1907, X.

Koganei (Y.) - Beiträge zur physichen Anthropologie der Aino: 2, Untersuchungen über die Lebenden. Tokyo, 1894;-Messungen an Chinesischen Soldaten. Mitt. Med. Fac. Univ. Tok., 1903, VI, 2.

Kohlbrugge (J. H. F.)-Anthropometrische Untersuchungen bei den Dyak. Mit. Nied. Reich. f. Völk., Haarlem, 1903, V;-L'Anthropologie des Tenggerois Indonésiens-montagnards de Java. L'Anthrop., 1898, IX, 1-25.

Kollman (J.)-Zur Anthropologie der Juden. Korr.-Bl. d. Ges. f. Anthrop. \& Urg., 1917, 1-5.

Korolew (S. A.)-Die Astrachanaschen Kalmucken. Arch.f. Anthrop., 1906, IV, 91.

Lapicque (M.)-Les nègres d'Asie et la race nègre en générale. Rev. Sc., 1906, VI.

Legendre (A. F.) -Etude anthropologique sur les Chinois du Setchuoen. Bull. \& Mém. Soc. Anthrop., Paris, 1910, II, No. 2, 77-94;-Far West Chinois:-Aborigines.-Lolos. ibid., 520-522.

Mainow (J.)-Die Jakuten. Arch. f. Anthrop., 1904, N. F. XI, 219.

Manouvrier (L.)-Étude sur les rapports anthropométriques en générale et sur les principales proportions du corps. Mém. Soc. Anthrop., Paris, 1902, II.

Marie (A.)-L'anthropométrie des Malagaches. L'Ethnographie, 1914, XV.

Martin (R.)-Die Inlandstämme der Malaischen Halbinseln, 1905;--Lehrbuch der Anthropologie. Jena, 1914.

McAuliffe (L.), A. Marie \& Thooris-Résultats des mensurations comparées de 100 soldats et de 100 aliénés epileptiques ou idiots. Bull. \& Mém. Soc. Anthrop., Paris, 1910, I, 307-311.

McDonald (A.)-Experimental Study of Children. Rep. Comm. U. S. Bur. Ed., 1899, 987-1390.

MacIver (R. D.) \& A. Wilkin-Libyan Notes, London, 1901.

Medico-Actuarial Mortality Investigation. 1912.

Merker (M.)-Die Masai. Berlin, 1910, 2 ed.

Mills (W. W.)-The Relation of Bodily Habitus to Visceral Form, Position, Tonus and Motility. Am.J. Roentg., 1917, IV, 155. 
Montoudon (G.) - Au pays Ghimirra. Neuchatel, 1913.

Paissel (W. E.)-Materialen zur Anthropologie der Tarantschen. Arch.f. Anthrop., 1901, XXVI, 176.

Papillault (G.)-L'homme moyen de Paris. Bull. Soc. Anthrop., Paris, 1902, III, 393-526;-Anthropométrie comparée de nègres africaines et de Français de deux sexes. Rev. Anthrop., 1911, XXI, 331, 536.

Pfitzner (W.) - Social anthropologische Studien: I. Der Einfluss der Lebensalters auf die anthropologischen Charactere. Zeitschr. f. Morph. u. Anthrop., 1889, I, 325-377;-Die Proportionen des erwachsenen Menschen. Zeitschr. f. Morph. u. Anthrop., 1902-3, V, 201-314.

Pittard (E.) - La taille, la grandeur du buste et des jambes, l'indice céphalique et l'indice nasal de 253 Tatars de la peninsule des Balkans. Bull. \& Mém. Soc. Anthrop., Paris, 1911, II, 432-441. Comparaisons de quelques caractéres somatologiques chez les Kurdes et chez les Arméniens. Rev. Anthrop., 1913, XXIII, 98-103. Contribution à l'étude anthropologique des Gagauz. Rev. anthrop., 1916, XXVI, 132.

Poutrin (L.)-Contribution à l'étude des pygmées d'Afrique (type brachycéphalique). L'Anthrop., 1910, XXI, 435-504;-Notes anthropologiques sur les nègres du Congo français. Bull. \& Mém. Soc. Anthrop., Paris, 1910, I, 33-47;-Notes anthropologiques sur les nègres du Congo. L'Anthrop., 1911, XXII, 420-519. (Type sous-dolicocéphalique).

Poutrin (L.) \& R. Gaillard-Etude anthropologique des populations des régions du Tehad et du Kanen. Doc. scient. mission Tilho, Paris, 3, 1914.

Preengruber-Observations anthropométriques sur 184 Kabyles de Palestre. Inedited, courtesy of Collignon-Giuffrida-Ruggeri, 1884.

Puccioni (N.)-Ricerce antrometriche sui Somali. Arch. p. l'Antrop. e l'Etnol., Firenze, 1911, 302;--Somali, Ibid; 1917, XLVII, 13-15.

Pyle (W. H.) - A Study of the Mental and Physical Characteristics of the Chinese. School \& Society, 1918, VIII, 264-268.

Pyle (W. H.) \& P. E. Collins-The Mental and Physical Measurements of Rural Children. Sch. \& Soc., 1918, VIII, 534-539.

Ranke (O.)-Beiträge zur Frage des kindlichen Wachstums. Arch. f. Anthrop., 1905, III, 161-180.

Ranke (J.)-Der Mensch. Leipzig \& Vienna, 1912.

Regnault (F.)-Essai sur les proportions du corps. Bull. Soc. Anthrop. Paris, 1905, IV, 276-291.

Reid (R. W.)-Remarks on 15 years of Anthropometric Work in the University of Aberdeen. J. Anat. \& Physiol., 1911-12, IV, 1.

Retzius (G.) \& C. M. Fürst-Anthropologia Suecica. Stockholm, 1902.

Reuter (F.)-Beiträge zur Anthropologie Hinterpommern. Arch.f. Anthrop., 1903, XXVIII, 289-338.

Rivet-Les Indiens de Mallasque. Bull. Soc. Anthrop., Paris, 1904, V, 144-152.

Roberts (C.)-The Physical Development and Proportions of the Human Body. St. George's Hospital Rep., 1877, VIII, 1-48;--Manual of Anthropometry. London, 1878.

A. C. Haddon, in Rose \& McDougal,--Pagan Tribes of Borneo. London.

Roudenko (S.)-Résultats de mensuration anthropologique sur les peuplades du nordouest de la Sibérie. Bull. \& Mém. Soc. Anthrop., Paris, 1914, V, 123-143. 
Roux (P.)-Contribution à l'étude anthropologique de l'Annamite Tonkinois. Bull. Soc. Anthrop., Paris, 1906, V, 321-350.

Ruelle (E.) - Notes anthropologiques, ethnographiques et sociologiques sur quelques populations noire du $2^{\circ}$ territoire militaire de l'Afrique occidentale française. l'Anthrop., 1904, XV, 657-703.

Sanchez-Fernandez (L.) -El hombre español util para servicio de las armas . . . sus caracteristicas antropologicas. Ass. Español. Prog. Ciencias, Granada, 1911.

Seaver (J. W.)-Anthropometry and Physical Examination. New Haven, 1909.

Seiner (F.)-Beobachtungen und Messungen an Buschleuten. Zeitschr. f. Ethnol, 1912, XLIV, 280-288.

Schellong (O)-Beiträge zur Anthropologie der Papuas. Zeitschr. f. Ethnol., 1891, XXIII, 156-230.

Schendrikowski (J. J.)-Beiträge zur Anthropologie der Sselengaschen Burjäten. Arch. f. Anthrop., 1910, XXVI, 156.

Schmidt (E.) \& P. Bartels-Beiträge zur Anthropologie Sudindiens. Arch. f. Anthrop., 1910, IX, 90-159.

Smedley (F. W.)-Report of the Department of Child Study. 46th Ann. Rep. Bd. Educ. Chicago, 1900.

Spencer (B.) \& F. J. Gillen-The Natives of Central Australia, 1899;--The Northern Tribes of Central Australia. 1904.

Spier (L.)--The Growth of Porto Rican Boys. J. Dent. Research., 1919, I, 1.

Starr (F.)-Physical Characters of the Indians of Southern Mexico. Chicago, 1902.

Stratz (C. H.)-Naturgeschichte des Menschen. Stuttgart, 1915;-Betrachtung über Wachstum des Menschen. Arch.f. Anthrop., 1904, XIV, 81-88.

Suk (V.) - Natives of Natal and Zululand. Unpublished. Courtesy of Dr. A. Hrdlička.

Sullivan (L. R.-Anthropometry of the Siouan Tribes. Am. Mus. Nat. Hist., 1920.

Thurston (E.) - Badagas and Irulas of the Nilgiris. Madras Gov. Mus., 1897;Anthropology of the Todas and Kotas. Ibid., 1896

Ten Kate (H.) -Observations anthropologiques recueillies dans la Guyane et le Vénézuela. Rev. d'Anthrop., 1887, LXIV;-Mélanges anthropologiques. L'Anthrop., 1914-17, XXV-XXVIII, 519-564, 569-583;-Indigènes de l'Archipel Timorien. L'Anthrop., 1915, XXVI, 519-564.

Teumin (S.)-Topographisch-anthropometrische Untersuchungen über die Proportions-verhältniss, des weiblichen Körpers. Arch. f. Anthrop., 1901, XXVII, 379.

Torii (R.)-Les aborigines de Formosa. J. Col.Sci. Imp. Univ. Tokyo, XXIII, 49.

Topinard (P.)-Rapport sur la population indigène de l'oasis de Biskra. Bull. Soc. Anthrop. Paris, 1870, sér. 2, V, 548-555;-Eléments d'anthropologie générale. Paris, 1885.

Tremearne (A. J. N.) - Notes on the Kagoro and other Nigerian Headhunters. $J$. Anthrop. Inst., 1912, XV, 136-199.

Tvarjanovic (J. K.)-Materialen zur Anthropologie der Armenier. Arch.f. Anthrop., 1910, XXVI, 181.

Vaillant (L.)-Contribution à l'étude anthropologique des Chinois. L'Anthrop., 1920, XXX, 8.

Verneau (R.) - Anthropologie et ethnologie de l'Ethiopie. 1916;-Résultats anthropologiques de la mission de M. de Gironcourt en l'Afrique occidentale. L'Anthrop., 1917, XXVII, 47, 211, 407, 542; XXVIII, 537, 568. 
Vram (N. G.)-Su alcuni carateri antropologici dei Cicci. Boll. Soc. Adr. Sc. Nat., Trieste, XXI, 216-217.

Walber (C.) -Beiträge zur Anthropologie der Letten. Dorpat, 1879.

Waldhauer (F.) - Über Anthropologie der Liver. Dorpat, 1877.

Weisbach (F.)-Körpermessungen verschiedener Menschenrassen. Berlin, 1877.

Weissenberg (S.) - Ein Beitrag zur Anthropologie der Turkvölker, Bashkiren und Meschtscherjaken. Zeitschr. f. Ethnol., 1892, 314;-Die südrussichen Juden. Arch. f. Anthrop., 1895, XXIII, 347-423;-Das Wachstum des Menschen nach Alter, Geschlecht und Rasse. Stuttgart, 1911.

Werner (H.)-Anthropologische Beobachtungen über die Heikum-und Kungbuschleute. Zieitschr. f. Ethnol., 1906, XXXVIII, 241-268. 